\title{
Srovnání osobností politických značek ČSSD, ODS a lídrů těchto stran
}

\author{
Comparison of the Political Brand Personalities of the Czech \\ Social Democratic Party, the Civic Democratic Party and Their \\ Leaders
}

\author{
Michal Žižlavský, Otto Eibl'
}

\begin{abstract}
Branding has recently become one of the most popular tools used by political marketers. In addition to its practical use, the branding approach to political marketing also offers new possibilities to political scientists researching how political brands are perceived by voters. One such tool is the concept of brand personality. This paper uses the brand personality concept to compare the brand personalities of the two main Czech political parties - the Czech Social Democratic Party and the Civic Democratic Party - and their leaders. To do so, it uses Jennifer Aaker's five-dimensional brand personality scale modified to for use on political brands and within the Czech political environment.
\end{abstract}

KEY WORDS brand, brand personality, Czech Social Democratic Party, Civic Democratic Party, leader

\section{Úvod}

Branding (neboli kultivace a péče o značku) je dalším významným nástrojem komerčního marketingu, který je v současné době inkorporován do marketingu politického. Mluvit o politických stranách či kandidátech jakožto o značkách (brandech) začíná být běžným jevem jak u politologů, tak i u samotných politiků. Podle Margaret Scammell (2007: 176) je zavádění brandingu do politické reality přirozeným procesem, a „zatímco spin doctoring a politická reklama byly běžným nástrojem politických stran a kandidátů uchylujících se k využivání politického marketingu v osmdesátých a devadesátých letech minulého století, je branding takovýmto nástrojem dnes“.

Př́nosem brandingového př́stupu pro politologický výzkum je možnost zkoumání toho, jak jednotliví zákazníci - voliči - politické strany či politiky vnímají jakožto značky. Toto poznání pak pomáhá stranám volit vhodnou komunikační a marketingovou strategii. Nečastěji využívaným nástrojem je $\mathrm{v}$ tomto př́ípadě koncept takzvané osobnosti značky

Sociálni studia. Katedra sociologie FSS MU, 3/2011. S. 65-95. ISSN 1214-813X.

1 Text vznikl v rámci výzkumného záměru „Politické strany a reprezentace zájmů v soudobých evropských demokraciích“ (kód MSM0021622407) a vychází z magisterské diplomové práce M. Žižlavského. 
(brand personality), kterému je věnována i tato práce. Naším primárním cílem je zodpovědět otázku, nakolik se shodují atributy spojované se značkou strany obecně s atributy spojovanými se značkou bývalých a současných lídrů ČSSD a ODS. K identifikaci dominantních osobnostních atributů jsme použili modifikovanou Smithovu (2009) škálu, čímž jsme navázali na výzkumy v oblasti politických značek prováděné v zahraničí. Samotný výzkum proběhl pomocí on-line dotazování studentů právnických fakult v České republice.

Text je členěn do dvou bloků. V prvním bloku bude představeno nezbytné minimum teorie značky, ve druhém bloku pak čtenáře seznámíme s použitou metodologií a výsledky výzkumu.

\section{Definice značky}

Abychom mohli politické subjekty chápat jako značky, je třeba si nejdřive adekvátně definovat značku jako takovou. Asi nejznámější definicí značky je definice Americké marketingové asociace (cit. podle Wood 2000: 664), která značku vymezuje jako ,jméno, termín, znak, symbol, design nebo jejich kombinaci, které jsou určeny k identifikování zboží nebo služeb jednoho či skupiny prodejců a k jejich odlišení od služeb nebo produktů konkurence“. Zmíněná definice ale pracuje především s vizuálními a hmotnými prvky, přičemž, jak zdůrazn̆uje Keller (2003: 3), marketingová praxe velmi často odkazuje ke značce jakožto k něčemu, co toto pojetí zdaleka př̌kračuje. Jde podle něj o „,vytvoření určité míry povědomí, reputace či prominence na daném trhu“.

Pro potřeby politologie se jako nejvhodnější jeví definice předložená Frenchem a Smithem (2008: 6), dle kterých můžeme definovat politickou značku jako asociativní sít' vzájemně propojených politických informací a postojů uložených v paměti voličů, které se aktivují, pokud jsou stimulovány. Voliči tak např́klad disponují znalostí jmen politických stran (ODS, ČSSD) či jejich symbolů (modrá holubice, oranžová růže), v průběhu času si s těmito jmény a symboly asociují určité významy, které se aktivují, pokud zaslechnout dané jméno či uvidí daný symbol. To jim následně pomáhá mezi stranami rozlišovat a rozhodovat se pro volbu jedné strany spíše než druhé.

Značka tedy neurčuje, co produkt je, ale jak ho voliči vnímají. Je zakořeněna v lidské mysli. Podle Tomze a Snidermana (2005: 4) politické subjekty jakožto značky vysílají vůči voličům signály, které jsou jednoduché, důvěryhodné, charakteristické a stabilní v rámci delších časových období a usnadňují jim tak orientaci v komplikované politické realitě.

\section{Osobnost značky}

Důležitým konceptem vztahujícím se ke značkám je takzvaná osobnost značky. Tu můžeme definovat jakožto ,sadu lidských vlastností spojovaných se značkou“ (Aaker 1997: 347), př́ípadně jako asociativní sít' lidských vlastností související s politickou stranou či politikem, uchovávanou v paměti voliče a prŕístupnou $\mathrm{v}$ prrípadě, kdy je v rámci této paměti vyvolána vnějším či vnitřním vjemem (Smith 2009: 212).

Spojovat lidské vlastnosti se značkami je možné, jelikož lidé personifikují neživé objekty prakticky neustále. Nejenom že jedinci pohlíží na neživé objekty, jako kdyby šlo 
o skutečné osoby, ale zároveň se k nim i tímto způsobem chovají (Jaabar 2010: 3). Podle Jennifer Aaker (1997: 348) se lidské vlastnosti značky utváří na základě jakéhokoliv př́mého či nepř́mého kontaktu jedince se značkou. Přímým zdrojem lidských osobnostních vlastností značky jsou jakékoliv lidské bytosti se značkou spojované, jelikož na ni v očích zákazníků přenáší vlastnosti své vlastní osobnosti. Mezi neprrímé zdroje vlastností pak patří takové faktory, jako jsou atributy produktu, jméno značky, její logo, demografický původ či způsob její propagace a distribuční kanály k tomu zvolené.

Pokud je osobnost značky efektivně komunikována směrem k zákazníkům, může celkově pozitivně ovlivnit jejich vnímání značky (Jaabar 2010: 3). Výhodou osobnostních asociací navíc je, že vytváŕí přímý vztah se zákazníkem (Sherrington 2003, cit. podle Jaabar 2010: 4) a že značka disponující pozitivní osobností k sobě navazuje emoce zákazníků, čímž napomáhá vytvoření voličské (zákaznické) loajality.

\section{Využití konceptu osobnosti značky pro výzkum politických značek}

Do politické reality koncept osobnosti značky převádí britský ekonom Gareth Smith, podle něhož (2009: 213) pomáhá dostatečně rozlišitelná osobnost politické značky vytvořit sadu jedinečných pozitivních asociací se značkou ve voličově paměti a přímo ovlivňuje voličovo volební chování. Smith (2009: 213) identifikuje čtyři hlavní faktory, které utváření osobnosti politické značky ovlivňují. Jsou jimi: 1) politické strany a politici sami o sobě, 2) kontrolovatelné a nekontrolovatelné politické události, 3) uživatelé značky a její podporovatelé (brand users a endorsers) a 4) reklama. Důležitou roli v tomto modelu hraje vztah voliče k dané politické straně, tedy jakási úroveň sympatí voliče k tomuto subjektu, jelikož ovlivňuje podobu vnímání informací, které osobnost značky dále utváří (Smith 2009: 213). Osobnost značky má důležitý vliv na voličovo volební chování, nejde ovšem o vliv jediný.

Výhodou konceptu osobnosti značky je jeho možná využitelnost jakožto nástroje umožňujícího empirický výzkum. Nejdále v tomto pokročil už zmíněný Smith (2009), který pro empirické testování osobnosti značek politických stran využivá škálu osobnosti značky vytvořenou Jennifer Aaker (viz níže), kterou testoval na příkladu dvou hlavních britských politických stran - Konzervativní strany (Conservative Party) a Labouristické strany (Labour Party) - na vzorku 183 studentů bakalářského oboru Business na nejmenované anglické univerzitě. Po původní aplikaci nezměněné škály přistoupil Smith k její modifikaci, aby co nejlépe reflektovala jak odlišnosti britského prostředí, tak její přenesení do prostředí výzkumu značek politických stran (viz níže). Tato práce navazuje na Smithův výzkum, přičemž dále modifikuje použitou metodu a rozšiřuje pole zkoumaných proměnných.

Vzhledem k tomu, že jakožto o politických značkách můžeme hovořit nejen o politických stranách, ale také o jejich představitelích, především pak lídrech, umožňuje nám koncept osobnosti značky testovat vztah mezi vnímáním osobností dvou různých entit (ČSSD, ODS) ze strany voličů a do určité míry i předpoklad, že osobnostní vlastnosti lídra strany přechází v myslích voličů na osobnost značky celé strany. Výzkumná otázka této práce je proto stanovena takto:

Do jaké míry se osobnosti značek lídrů ČSSD a ODS podobaji osobnostem značek těchto stran? 
V době sběru dat, tedy na přelomu dubna a května 2011, nám sociopolitické podmínky české politiky nabídly ve vztahu k výzkumné otázce velice atraktivní situaci. Jak ČSSD, tak ODS se totiž nacházely ve stádiu, kdy v relativně nedávné době došlo ke změně na postech lídrů (Petr Nečas v době konání výzkumu fakticky vedl ODS zhruba 14 měsíců, Bohuslav Sobotka stál v čele ČSSD 12 měsíců), a bylo tedy možné zkoumat i to, zda s novým lídrem dochází k posunu ve vnímání strany jako celku či nikoliv. U obou stran navíc došlo k výměně poměrně výrazných osobností za osobnosti s bohatou (a dlouholetou) stranickou minulostí, nicméně noví lídři nebyli (ve srovnání s J. Paroubkem a M. Topolánkem) natolik (mediálně) razantní. Vzhledem k této situaci se pak k testování nabídly následující hypotézy:

Hypotéza 1: Osobnosti značek ČSSD a ODS se podobaji osobnostem značek svých lídrů.

Hypotéza 2: Osobnosti značek bývalých lidrů ČSSD a ODS, se podobaji osobnostem značek ČSSD a ODS více, než osobnosti značek jejich současných lídrů.

\section{Škály pro měření osobnosti značek}

\section{Škála pro měření osobnosti komerčních značek}

$\mathrm{V}$ rámci komerčního marketingu bývá pro výzkum osobnosti značky nejčastěji využívána už zmíněná škála pro měření osobnosti komerčních značek vytvořená v roce 1997 Američankou Jennifer Aaker. Aaker se při jejím vytváření inspirovala psychologií a takzvanou „Velkou pětkou“ (Big Five) dimenzí lidské osobnosti, které bývají psychology lidským jedincům obvykle přisuzovány.

Aaker si osobnost značky definovala jako „sadu lidských vlastností spojovaných se značkou“ (Aaker 1997: 347) a následně se v několika krocích empirickým testováním souboru osobnostních vlastností odvozených ze tří zdrojů (kvalitativního výzkumu, škál použivaných psychology a škál používaných pracovníky marketingu) na známých komerčních značkách dobrala finální škály, obsahující ve výsledku pět osobnostních dimenzí (dimensions), složených z celkem 42 individuálních osobnostních vlastností (traits). Kompletní škálu v českém překladu nabízí schéma 1.

\section{Škála pro měření osobnosti politických značek}

Jak už bylo uvedeno výše, škálu Jennifer Aaker přenáší do politického prostředí Smith (2009). Ten ji po prvotní aplikaci v její původní podobě upravil tak, aby co nejlépe reflektovala jak odlišnosti britského prostředí, tak přenesení do prostředí výzkumu značek politických stran. Z původní škály Smith odfiltroval vlastnosti, které byly v britském prostředí matoucí a neměly odpovídající výpovědní hodnotu (celkově odstranil osm vlastností - rodinně zaměřený, maloměstský, soudržný, šik, vyšši třída, okouzlujicí, ženský a západni). Dále reformuloval názvy jednotlivých dimenzí, aby lépe odpovídaly politické realitě, přeskupil jednotlivé vlastnosti $\mathrm{v}$ rámci těchto dimenzí a $\mathrm{v}$ neposlední také přidal šestou specifickou dimenzi jedinečnost, do které zahrnul tři vlastnosti poukazující na odlišnost dané značky politické strany od ostatních. Jde o vlastnosti jedinečný, nezávislý a originální. Ve výsledku tak Smithova škála obsahuje celkem 34 vlastností podřazených do šesti různých dimenzí. Smithovu škálu v českém překladu můžete najít jakožto schéma 2. 
Michal Žižlavský, Otto Eibl: Srovnání osobností politických značek ČSSD, ODS a lídrů těchto stran

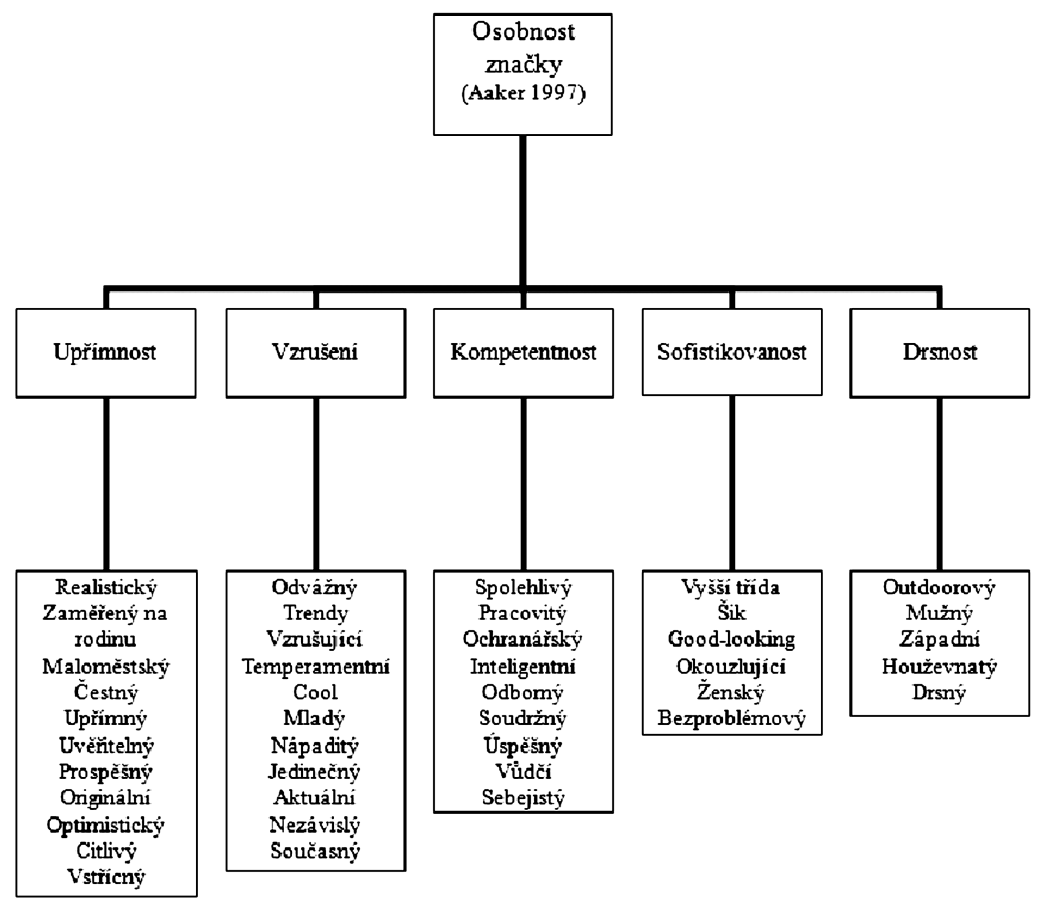

Schéma 1: Škála osobnosti značky podle Jennifer Aaker Zdroj: Smith 2009: 230.

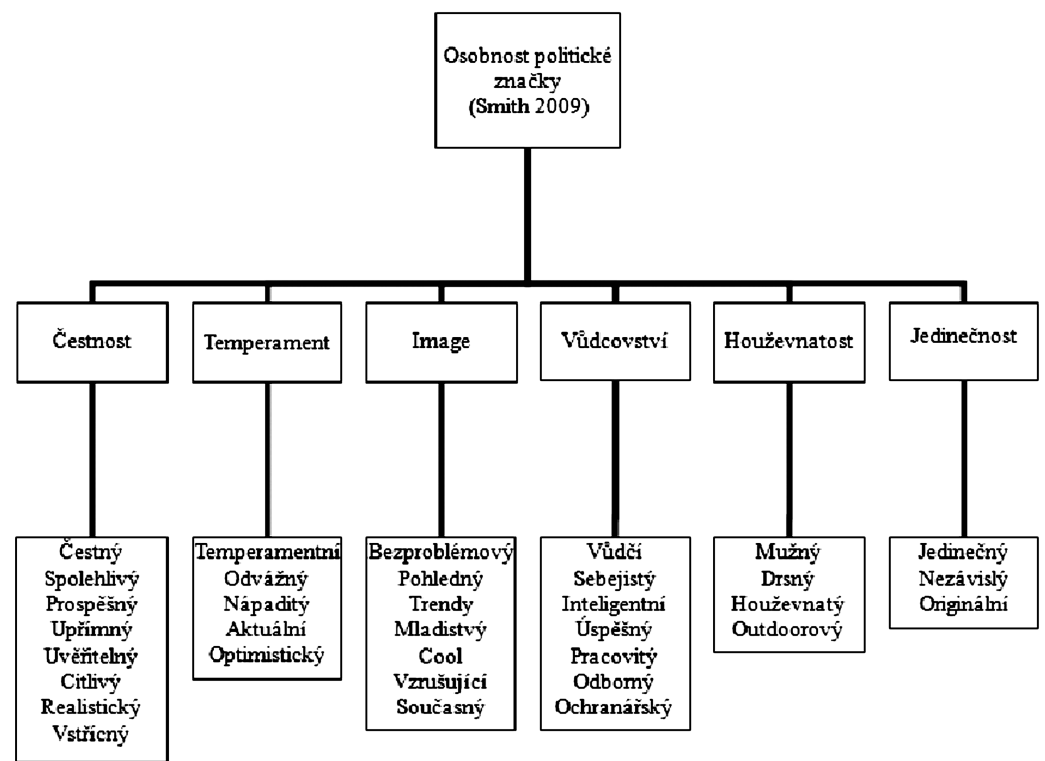

Schéma 2: Smithova škála osobnosti politické značky Zdroj: Smith 2009: 220. 


\section{Adaptace Smithovy škály pro měření osobnosti politické značky na české} prostředí

Škála $\mathrm{v}$ úpravách Smithe $\mathrm{s}$ sebou ovšem nese určité limitace, které je potřeba pro potřeby našeho výzkumu odstranit. Jsou jimi: 1) anglický jazyk, 2) adaptace škály na výzkum osobnosti značky politických stran a 3) adaptace škály na prostředí Velké Británie.

Řešením první limitace je překlad škály do českého jazyka. Jelikož na sebe ale přenesení škály z jednoho jazyka do druhého váže riziko ztráty původního významu jednotlivých osobnostních vlastností, byl tento překlad konzultován s pěti experty na lingvistiku z Katedry anglistiky a amerikanistiky Filosofické fakulty Masarykovy university. Přeloženo bylo všech 42 osobnostních vlastností z původní škály vytvořené Jennifer Aaker. Škály v rámci tohoto textu jsou všechny uváděny v českém znění na základě tohoto př̀kladu.

Druhou limitací je adaptace škály upravené Smithem pro výzkum politických stran. Problematická $\mathrm{v}$ tomto případě není změna názvu jednotlivých osobnostních dimenzí a přesunutí jednotlivých vlastností, k němuž oproti původnímu konceptu Jennifer Aaker došlo, ale přidání šesté dimenze jedinečnost. Ta totiž plní svoji funkci při aplikaci na politické strany, její aplikace na politiky ovšem může vyvolávat pochybnosti, zdali je možné jedinečnost skutečně chápat jakožto dimenzi lidské osobnosti. Pro odstranění tohoto limitu tedy došlo k vypuštění nově zavedené šesté dimenze a ponechání pouze pěti dimenzí, tak jak je pro výzkum politického prostředí upravuje Smith. Vlastnosti jedinečný, nezávislý a originální byly přesunuty do těchto zbývajících dimenzí.

Poslední, třetí limitací je adaptace škály na politické prostředí Velké Británie, které se od politického prostředí České republiky v mnohém liší. Podobně jako Smith vybral z původních 42 vlastností škály Jennifer Aaker 34 nejpoužitelnějších pro britské prostředí, byly pro potřeby této práce vybrány vlastnosti, které jsou nejsrozumitelnější a nejadekvátnější pro použití v českém prostředí. Pro výběr byla opět použita kompletní sada Jennifer Aaker. Z této sady byly následně na základě konzultace se třemi odborníky na politický marketing a politickou komunikaci z Katedry politologie Masarykovy univerzity vyřazeny vlastnosti vyšš $i$ třída, ženský, západní, soudržný, šik, outdoorový. Ve srovnání se Smithem byly tedy ve škále ponechány vlastnosti rodinně založený, maloměstský a okouzlujicí, vyřazena byla naopak vlastnost outdoorový. Celkově bylo dosaženo škály o pěti dimenzích obsahující celkem 36 osobnostních vlastností. Kompletní škálu nám ukazuje schéma 3.

Modifikovaná škála byla následně testována na vzorku 44 studentů vysokých škol různých oborů ve věku 20-26 let. Tento vzorek je typově podobný vzorku, který byl následně použit v samotném výzkumu. $\mathrm{V}$ rámci dotazníku použitého při pretestu došlo $\mathrm{k}$ jedné zásadní změně oproti původnímu Smithovu dotazníku. ${ }^{2}$ Gareth Smith totiž jednotlivé osobnostní vlastnosti vyňal ze zmíněných dimenzí a promíchal je mezi sebou, tudíž respondenti nebyli $\mathrm{s}$ jejich zařazením do jednotlivých dimenzí seznámeni, a posuzovali tak jednotlivé vlastnosti nezávisle na jakémkoliv kontextu. Tento postup byl ovšem při konzultaci s lingvistickými experty z Masarykovy univerzity vyhodnocen jakožto chybný, jelikož respondenti tím ztrácí pojem o daném významu výrazu, který vychází z určitého kontextu vytvářeného právě jeho

2 Originální dotazník poskytl pro účely této práce Gareth Smith. 
zařazením do dané dimenze společně s ostatními osobnostními vlastnostmi. V rámci našeho výzkumu proto byli respondenti se zařazením zmíněných výrazů do jednotlivých dimenzí seznámeni.

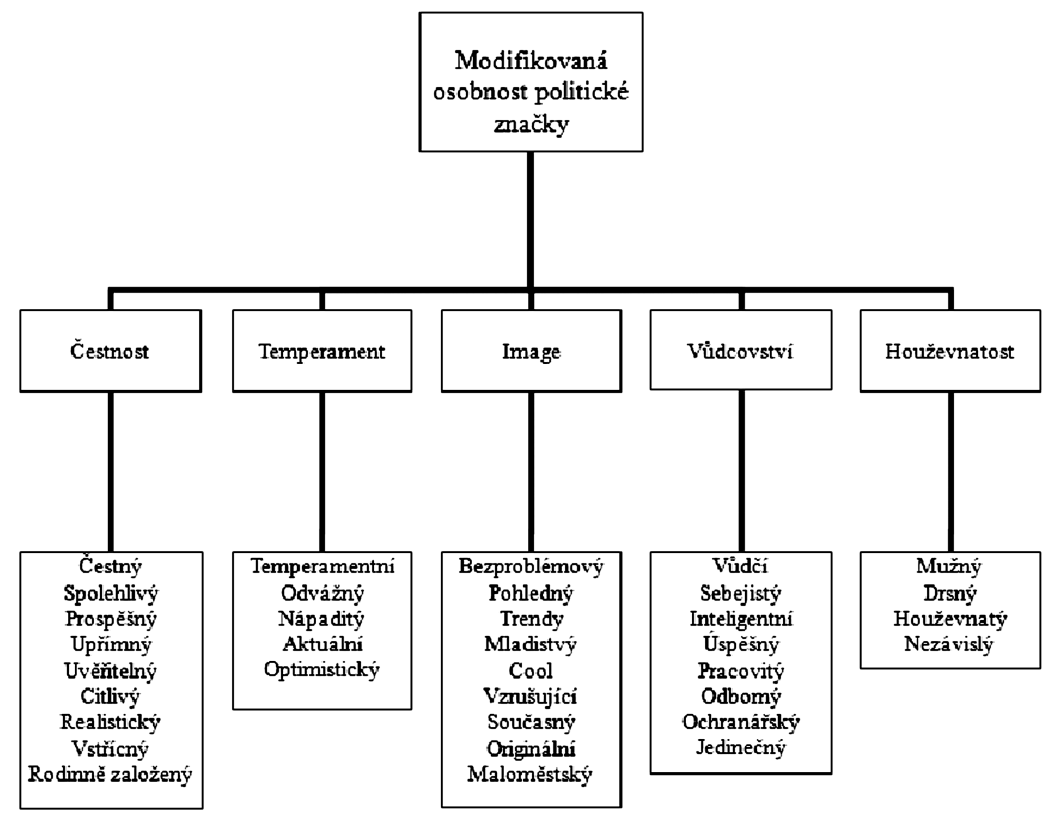

Schéma 3: Pro české prostředí modifikovaná škála osobnosti politické značky

Pretest měl za cíl ověřit zejména reliabilitu použité škály. Při pohledu na tabulku 1 , která reportuje výsledky testování reliability (za pomocí Cronbachovy Alfy), je zřejmé, že škály jsou vnitřně konzistentní, reliabilní a vhodné pro použití pro vlastní výzkum.

Tabulka 1: Reliabilita modifikované škály měření osobnosti politické značky v rámci pretestu

\begin{tabular}{|l|c|}
\hline Dimenze & Crombachova alfa \\
\hline Čestnost & 0,892 \\
\hline Temperament & 0,761 \\
\hline Image & 0,863 \\
\hline Vůdcovství & 0,815 \\
\hline Houževnatost & 0,827 \\
\hline
\end{tabular}




\section{Metodika výzkumu a výběr vzorku respondentů}

\section{Metodika srovnání osobnosti značek politických stran a jejich lídrů}

Poté, co jsme modifikovali škálu a otestovali její reliabilitu, bylo nutné si stanovit vhodnou metodu, která by nám umožnila adekvátní srovnání osobnosti značek jednotlivých politických stran a jejich lídrů. Pro větší přesnost výsledků a zároveň pro zachování rozčlenění osobnostních vlastností do jednotlivých dimenzí byly osobnosti značek srovnávány hned na dvou úrovních, a to na úrovni jednotlivých vlastností a poté také na úrovni osobnostních dimenzí.

Na každé z těchto úrovní byla dále srovnávána podobnost, respektive odlišnost osobností značek politických stran a jejich lídrů trojím způsobem. Ze všeho nejdříve byl u každé osobnostní vlastnosti jednotlivých politiků jednoduchým odečtením vypočítán rozdíl, kterým se liší od téže vlastnosti dané politické strany. Záporné hodnoty byly přitom převedeny na kladné, což nám umožnilo tyto rozdíly následně sečíst a stanovit si celkovou hodnotu odlišnosti osobnosti značky daného lídra od jeho strany. V př́ípadě hodnoty celkové odlišnosti platí, že čím vyšší je toto číslo, tím více se osobnost značky lídra liší od osobnosti značky dané strany. $\mathrm{V}$ př́ípadě nulové hodnoty by pak byly obě osobnosti identické.

U jednotlivých rozdílů byl poté vypočítán aritmetický průměr, který udal průměrnou hodnotu odlišnosti jednotlivých osobnostních vlastností mezi stranou a jejím lídrem.

V neposlední řadě byl spočítán variační koeficient ${ }^{3}$ rozdílů jednotlivých osobnostních vlastností, abychom zodpověděli otázku, do jaké míry se rozložení jednotlivých osobnostních vlastností lídrů odlišují od osobnostních vlastností značky stran. Jinými slovy nám tedy pomáhá zjistit, zdali osobnosti značky lídrů obecně disponují podobně rozloženými osobnostními vlastnostmi jako osobnosti značky stran a liší se od nich pouze v intenzitě jejich vnímání, nebo jestli spíše disponují osobnostními vlastnostmi, které se od těch stranických liší.

\section{Výběr vzorku respondentů}

Vzorek respondentů tvořili studenti vysokoškolského magisterského oboru Právo ze všech čtyř univerzit, které toto studium v České republice poskytují. Motivací pro výběr tohoto vzorku byla jeho kompaktnost, dostatečná velikost a také předpokládaný zájem o politické dění v České republice. Ačkoliv tedy zjevně nejde o reprezentativní voličský vzorek, jeho relativní homogenita jakožto skupiny (co se týče věku, pohlaví, vzdělání atd.), jak argumentuje mimo jiné i Smith (2009: 219), poslouží dobře pro testování pionýrské metody zaváděné v této práci.

Celkový počet respondentů, kteří se zapojili do dotazníkového šetření, byl $265 .{ }^{4}$ Pouze 181 z nich poté vyplnilo dotazník celý. V rámci výzkumu byla ovšem použita data

3 Variační koeficient přibližuje variabilitu rozložení pravděpodobnosti náhodné veličiny a je definován jako podíl směrodatné odchylky a absolutní hodnoty ze střední hodnoty, tedy vypočítán podle vzorce: směrodatná odchylka/průměr*100. Obecně platí, že čím vyšší jsou hodnoty koeficientu, tím větší jsou i jednotlivé rozdíly (Eibl, Havlík, Kyloušek a Pink 2009: 121).

4 U 49,4 \%, tedy téměř poloviny z výše uvedených 265 studentů, šlo o studenty Masarykovy univerzity v Brně $(\mathrm{N}=131), 25,7 \%$ bylo studenty Palackého univerzity v Olomouci $(\mathrm{N}=68), 17,4$ \% 
i z dotazníků, které nebyly vyplněny celé, jelikož jde i přes tento handicap o data relevantní a použitelná. U všech analyzovaných proměnných je proto uveden počet respondentů $(\mathrm{N})$, kteří na dané otázky odpovídali.

K samotnému sběru dat došlo v období mezi 24. 4. 2011 a 14. 5. 2011. Pro tvorbu dotazníků byla vybrána elektronická forma za pomoci on-line dostupného analytického nástroje Qualtrics.com. Pro distribuci dotazníků byla zvolena technika sněhové koule - o rozšíření prvotní informace o výzkumu (a výzvu k dalšímu šíření dotazníku) mezi studenty byla požádána studentská právnická organizace ELSA, respektive její regionální kanceláře.

\section{Reliabilita měření pomocí modifikované škály osobnosti značky během výzkumu}

Výsledky měření byly podrobeny testu reliability na základě Crombachova Alfa. ${ }^{5} \mathrm{Ta}$ i v tomto případě vyšla stejně jako u pretestu u všech měřených dimenzí vyšší než požadovaných 0,7 , a výsledek měření tak můžeme považovat za reliabilní. Výsledky u jednotlivých dimenzí ukazuje tabulka 2.

Tabulka 2: Reliabilita měření pomocí modifikované škály osobnosti značky během výzkumu

\begin{tabular}{|l|c|}
\hline Dimenze & Crombachova alfa \\
\hline Čestnost & 0,921 \\
\hline Temperament & 0,802 \\
\hline Image & 0,865 \\
\hline Vůdcovství & 0,825 \\
\hline Houževnatost & 0,821 \\
\hline
\end{tabular}

\section{Limitace výzkumu}

Mezi největší limity výzkumu patří bezesporu omezený vzorek respondentů, který není reprezentativním vzorkem voličské základny v České republice. Další limitací je také použití elektronické formy dotazníků a techniky sněhové koule ${ }^{6}$ pro jejich distribuci, které ve vzájemné kombinaci způsobují poměrně malou návratnost a také určitý samovýběr respondentů. Ambicí výzkumu ovšem není maximální reprezentativnost a objektivnost dat, ale především otestování škály osobnosti značky jakožto nástroje pro výzkum politických značek v českém prostředí, a zároveň pokus o odhalení existence či neexistence vztahů mezi osobnostmi značek politických stran a jejich lídrů, které by měly být dostatečně zřetelně rozpoznatelné i na vzorku, který byl pro výzkum použit.

tvořili studenti Karlovy univerzity v Praze $(\mathrm{N}=46)$ a 7,5 \% studenti Západočeské univerzity v Plzni $(\mathrm{N}=20)$. Co se pohlaví respondentů týče, tvořily vzorek z $54 \%$ ženy $(\mathrm{N}=143)$ a ze $46 \%$ muži $(\mathrm{N}=122)$. Věkový průměr respondentů se pohyboval okolo 22,8 let.

5 Reliabilitu můžeme definovat jakožto ,přesnost, konzistentnost měření, tj. schopnost dosáhnout stejného výsledku měření v př́ípadě, že se stav pozorovaného předmětu nezměnil“ (Soukup 2006).

6 Podle Dismana (2000: 114) tato technika ,spočívá ve výběru jedinců, při kterém nás nějaký původní informátor vede k jiným členům naší cílové skupiny“. 
Důležitou limitací, spojenou tentokrát s relevantností výzkumu samotného, je pak to, že jeho zjištění nám neumožňují jednoznačně potvrdit či vyvrátit vyslovený předpoklad, že osobnostní vlastnosti lídra strany přechází v mysli voliče na stranu samotnou. Výzkum nám sice dokáže odpovědět na otázku, jestli se osobnostní vlastnosti značky strany a lídra podobají, ne už ovšem na to, jestli tyto vlastnosti přechází z lídra na stranu či ze strany na lídra, nebo jestli spolu př́ípadná podobnost těchto vlastností skutečně souvisí. Významnou limitací je také nemožnost objektivního stanovení hranice, kdy se strana a lídr ještě stále podobají a kdy už o podobnost nejde. Dlouhodobý výzkum za použití dané metody by mohl vést k odstranění těchto nedostatků a stát se účinným nástrojem schopným mechanismus přenosu vlastností lídra na stranu (a opačně) odhalit.

\section{Asociace politikư se stranami}

Respondenti byli ze všeho nejdříve tázáni na jméno politika ČSSD, respektive ODS, který se jim jako první vybaví ve spojení s touto stranou. Na tuto otázku odpovědělo všech 265 respondentů.

Nejčastěji jmenovaným politikem ODS byl její současný předseda a také předseda vlády Petr Nečas. Toho jako první asociaci s ODS uvedlo 40,75 \% (N=108) dotázaných. Jen o trochu méně často jmenovali respondenti bývalého předsedu Mirka Topolánka, na kterého si vzpomnělo 36,22 \% $(\mathrm{N}=96)$. Významný podíl 15,48 \% $(\mathrm{N}=41)$ získal také prezident republiky a zakladatel ODS Václav Klaus. Vedle těchto politiků byl vícekrát zmíněn také bývalý předseda poslaneckého klubu ODS Petr Tluchoř, v době sběru dat medializovaný ve vztahu ke skandalizované nahrávce rozhovoru s bývalou předsedkyní poslaneckého klubu Věcí veřejných Kristýnou Kočí $(1,88 \%, \mathrm{~N}=5)$, bývalý primátor Prahy Pavel Bém $(1,13 \%, \mathrm{~N}=3)$, ministr spravedlnosti a bývalý děkan právnické fakulty Západočeské univerzity v Plzni Jiří Pospíšil $(1,13 \%, N=3)$ a dvakrát respondenti uvedli také ,jác“, čímž chtěli zrejejě upozornit na své členství v ODS. Za pozornost také stojí, že ve dvou př́padech respondenti uvedli jako politiky ODS také dva bývalé předsedy konkurenční ČSSD Stanislava Grosse a Miloše Zemana. Úplný výčet zmíněných politiků nabízí tabulka 3.

Tabulka 3: Politici jmenovaní respondenty jako první ve vztahu k ODS

\begin{tabular}{|l|c|c|}
\hline Politik & $\mathbf{N}$ & $\mathbf{1 0 0 \%}$ \\
\hline Petr Nečas & 108 & 40,75 \\
\hline Mirek Topolánek & 96 & 36,22 \\
\hline Václav Klaus & 41 & 15,48 \\
\hline Petr Tluchoř & 5 & 1,88 \\
\hline Pavel Bém & 3 & 1,13 \\
\hline Jiř́ Pospíšil & 3 & 1,13 \\
\hline Já & 2 & 0,75 \\
\hline Jednou zmínění (0,38 \%) byli dále Přemysl Sobotka, Jaroslav Kubera, Miroslava Němcová, Ivan Langer, \\
Marek Benda a dokonce i Stanislav Gross a Miloš Zeman. \\
\hline \multicolumn{2}{|c|}{} \\
\hline
\end{tabular}


Nejčastěji jmenovaným politikem ČSSD byl bývalý předseda strany Jiří Paroubek, na kterého si jako na prvního vzpomnělo celkem $66,79 \%(\mathrm{~N}=177)$ respondentů. Jako druhého poté nejčastěji jmenovali respondenti současného předsedu ČSSD Bohuslava Sobotku, na kterého si ovšem vzpomnělo pouhých $18,49 \%(\mathrm{~N}=49)$, tedy více než 3,5krát méně než na Jiř́iho Paroubka. Třetím nejčastěji uváděným politikem byl bývalý předseda strany Miloš Zeman s 8,68 \% $(\mathrm{N}=23)$. Opakovaně respondenti jmenovali ještě místopředsedu strany Zdeňka Škromacha $(2,64 \%, \mathrm{~N}=7)$, prvního místopředsedu strany a jihomoravského hejtmana Michala Haška $(1,51 \%, \mathrm{~N}=4)$ a břeclavského místostarostu Jaroslava Parolka $(0,75 \%, N=2)$. Úplný výčet zmíněných politiků nabízí tabulka 4 .

Tabulka 4: Politici jmenovaní respondenty jako první ve vztahu k ČSSD

\begin{tabular}{|l|c|c|}
\hline Politik & $\mathbf{N}$ & $\mathbf{1 0 0 \%}$ \\
\hline Jiř́ Paroubek & 177 & 66,79 \\
\hline Bohuslav Sobotka & 49 & 18,49 \\
\hline Miloš Zeman & 23 & 8,68 \\
\hline Zdeněk Škromach & 7 & 2,64 \\
\hline Michal Hašek & 4 & 1,51 \\
\hline Jaroslav Parolek & 2 & 0,75 \\
\hline Jednou zmínění (0,38 \%) byli dále David Rath, Stanislav Gross a Vladimír Špidla. \\
\hline
\end{tabular}

Pokud budeme politika, kterého má volič nejsilněji asociovaného se stranou a kterého si proto jako prvního vybaví ve spojení s ní, brát jako neprímý indikátor přenosu osobnostních vlastností lídra na značku dané strany, mohli bychom na základě výše uvedených dat předpokládat, že zatímco u ODS se bude osobnost značky strany shodovat nejspíše s osobností značky Petra Nečase, zároveň ovšem nebude př́liš rozdílná ani od osobnosti značky Mirka Topolánka, u ČSSD bude shodná ve velké míře s osobností značky Jiřího Paroubka, od osobnosti značky Bohuslava Sobotky se však může potenciálně značně odlišovat. Jestli tomu tak skutečně je, nebo není, nám potvrdí či vyvrátí následující kapitoly.

\section{Charakteristické osobnostní vlastnosti značek politických subjektů}

V následující kapitole se nejdříve podíváme konkrétněji na jednotlivé osobnostní vlastnosti značek zkoumaných politických stran a politiků. Získaná data nám také u každého z nich umožní určit, které osobnostní vlastnosti jsou u jednotlivých subjektů vnímány danou skupinou respondentů jako nejsilnější (potažmo jako nejslabší), a jsou (potažmo nejsou) tak pro tuto politickou značku charakteristické. Za takovéto vlastnosti budeme považovat veškeré vlastnosti, jejichž hodnoty dosáhly nadprůměrných výsledků, tedy překročily na měřené škále hodnotu ,3“. 


\section{Osobnostní vlastnosti značek ČSSD a ODS}

Již letmý pohled na graf 1 dává tušit, že osobnostní charakteristiky obou stran jsou značně rozdílné a jasně odlišitelné. $V$ drtivé většině sledovaných kategorií pak lepších hodnot nabývá, respektive je lépe vnímaná ODS, což ovšem může být dáno doprava směřujícími stranickými preferencemi relativně homogenního vzorku, na kterém byl výzkum proveden. ${ }^{7}$

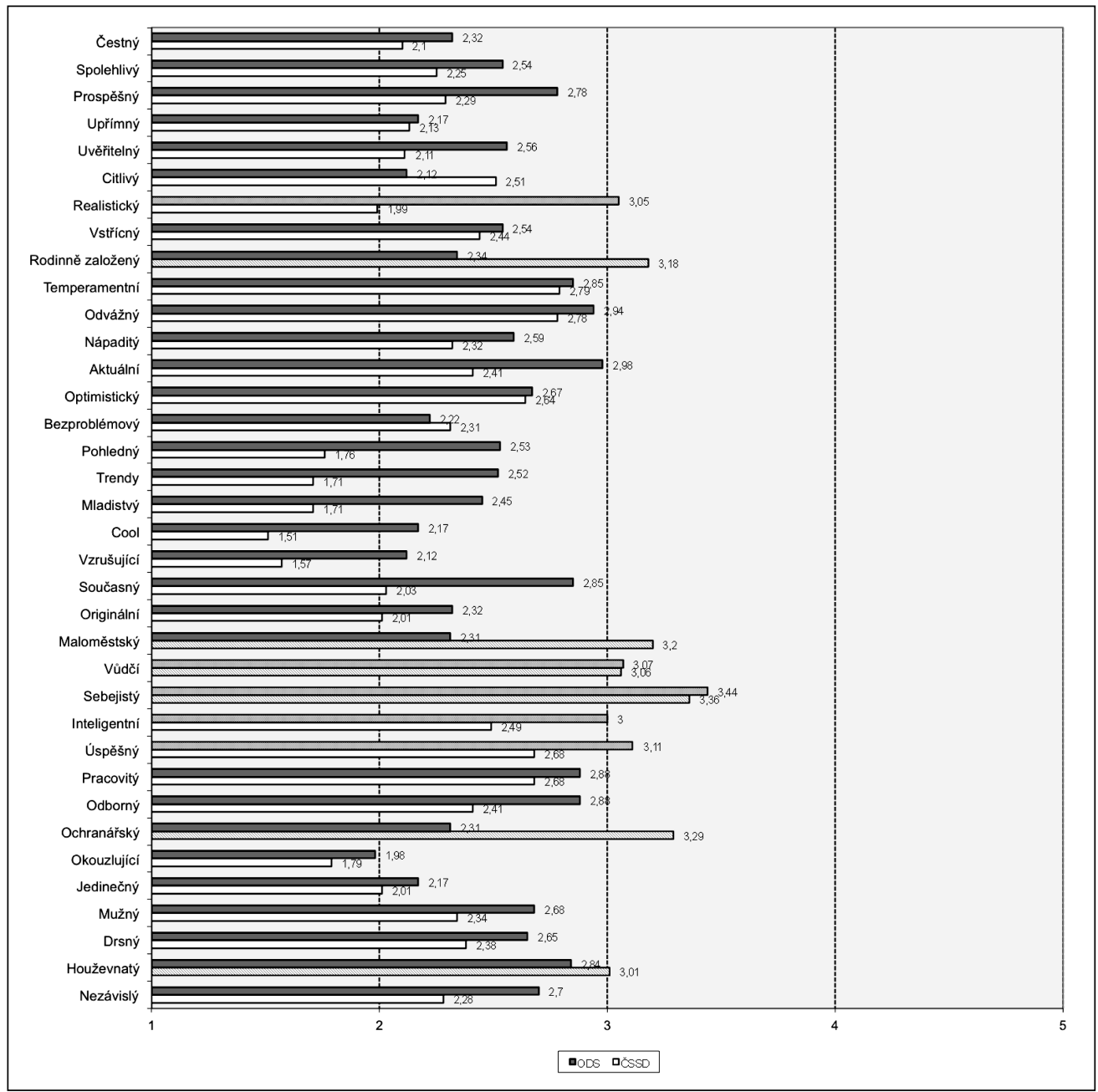

Graf 1: Osobnostní charakteristiky značek ČSSD a ODS

7 Ve výzkumu bylo zjišt'ováno i to, jakou stranu by respondent volil. Bohužel na tuto otázku odpovědělo prŕliš málo respondentů na to, aby bylo možné vyvozovat obecně platné závěry. Z výsledků však byla patrná slabá tendence favorizovat strany, které lze přiřadit spíše k pravici. 
Na druhou stranu kategorie, ve kterých je lépe hodnocena ČSSD, jsou pro stranu „charakteristické“ ve vztahu k programatice a rétorice, se kterou usiluje o př́zeň voličů - jde o kategorie citlivý, rodinně založený, ochranářrký a houževnatý. Další kategorií, kde ČSSD předstihuje ODS, je kategorie maloměštácký, kterou nesmíme vnímat pejorativně, ale spíše jako „lidovou" charakteristiku strany.

Největší rozdíl mezi oběma konkurenčními stranami lze vysledovat zejména v kategoriích spadajících do oblasti image, kde ODS dosahuje citelně lepších hodnot než ČSSD. Při pohledu na hodnoty jednotlivých stran konstatujeme, že osobnostní vlastnosti značky ODS dosáhly středové (a vyšší) hodnoty v pěti případech. Nejsilněji respondenti $(\mathrm{N}=130)$ vnímají značku ODS jakožto sebejistou $(3,44)$, úspěšnou $(3,11)$, vůdči $(3,07)$, realistickou $(3,05)$ a inteligentní (3). V př́ípadě ČSSD jsme pak středovou a vyšší hodnotu zaznamenali v šesti případech. Nejsilněji respondenti $(\mathrm{N}=112)$ vnímají značku ČSSD jako sebejistou $(3,36)$, ochranářskou $(3,29)$, maloměstskou $(3,2)$, rodinně založenou $(3,18)$, vi̊dči $(3,06)$, realistickou $(3,05)$ a houževnatou $(3,01)$.

Podrobný přehled výsledků jednotlivých osobnostních vlastností nabízí graf 1 , respektive tabulka 5.

Poznámka: Zvýrazněné jsou kategorie, kde strany dosahují hodnoty „3“ nebo vy̌̌ší.

Tabulka 5: Osobnostní charakteristiky značek ČSSD a ODS

\begin{tabular}{|c|c|c|c|c|c|}
\hline & & \multicolumn{2}{|c|}{ ČSSD } & \multicolumn{2}{|c|}{ ODS } \\
\hline & & Prưmèr & Sm. odch. & Průměr & Sm. odch. \\
\hline \multirow{9}{*}{ Čestnost } & Čestný & 2,1 & 0,968 & 2,32 & 0,966 \\
\hline & Spolehlivý & 2,25 & 1,018 & 2,54 & 0,925 \\
\hline & Prospěšný & 2,29 & 1,112 & 2,78 & 1,080 \\
\hline & Uprímný & 2,13 & 1,075 & 2,17 & 1,013 \\
\hline & Uvěřitelný & 2,11 & 1,025 & 2,56 & 0,940 \\
\hline & Citlivý & 2,51 & 1,208 & 2,12 & 0,981 \\
\hline & Realistický & 1,99 & 1,189 & 3,05 & 1,209 \\
\hline & Vstřícný & 2,44 & 1,206 & 2,54 & 0,908 \\
\hline & Rodinně založený & 3,18 & 1,141 & 2,34 & 1,118 \\
\hline \multirow{5}{*}{ Temperament } & Temperamentní & 2,79 & 1,035 & 2,85 & 1,086 \\
\hline & Odvážný & 2,78 & 1,168 & 2,94 & 1,081 \\
\hline & Nápaditý & 2,32 & 1,141 & 2,59 & 0,929 \\
\hline & Aktuální & 2,41 & 0,964 & 2,98 & 1,045 \\
\hline & Optimistický & 2,64 & 1,287 & 2,67 & 0,951 \\
\hline
\end{tabular}




\begin{tabular}{|c|c|c|c|c|c|}
\hline & & \multicolumn{2}{|c|}{ ČSSD } & \multicolumn{2}{|c|}{ ODS } \\
\hline & & Průmèr & Sm. odch. & Průmèr & Sm. odch. \\
\hline \multirow{9}{*}{ Image } & Bezproblémový & 2,31 & 1,000 & 2,22 & 1,051 \\
\hline & Pohledný & 1,76 & 1,050 & 2,53 & 1,087 \\
\hline & Trendy & 1,71 & 1,019 & 2,52 & 1,021 \\
\hline & Mladistvý & 1,71 & 1,043 & 2,45 & 1,012 \\
\hline & Cool & 1,51 & 0,968 & 2,17 & 1,101 \\
\hline & Vzrušující & 1,57 & 1,054 & 2,12 & 1,083 \\
\hline & Současný & 2,03 & 1,018 & 2,85 & 1,053 \\
\hline & Originální & 2,01 & 0,982 & 2,32 & 0,966 \\
\hline & Maloměstský & 3,2 & 1,374 & 2,31 & 1,317 \\
\hline \multirow{9}{*}{ Vůdcovství } & Vůdčí & 3,06 & 1,076 & 3,07 & 1,167 \\
\hline & Sebejistý & 3,36 & 1,114 & 3,44 & 1,300 \\
\hline & Inteligentní & 2,49 & 1,004 & 3 & 1,124 \\
\hline & Úspěšný & 2,68 & 1,092 & 3,11 & 1,082 \\
\hline & Pracovitý & 2,68 & 1,006 & 2,88 & 1,040 \\
\hline & Odborný & 2,41 & 0,973 & 2,88 & 1,114 \\
\hline & Ochranářský & 3,29 & 1,249 & 2,31 & 0,959 \\
\hline & Okouzlující & 1,79 & 1,052 & 1,98 & 1,043 \\
\hline & Jedinečný & 2,01 & 1,219 & 2,17 & 1,071 \\
\hline \multirow{4}{*}{ Houževnatost } & Mužný & 2,34 & 1,046 & 2,68 & 1,042 \\
\hline & Drsný & 2,38 & 1,113 & 2,65 & 1,069 \\
\hline & Houževnatý & 3,01 & 1,178 & 2,84 & 1,084 \\
\hline & Nezávislý & 2,28 & 1,062 & 2,7 & 1,061 \\
\hline
\end{tabular}

Poznámka: Tučně zvýrazněné jsou kategorie, kde strany dosahují hodnoty „3“ nebo vyšší. Kurzívou zvýrazněné jsou kategorie, kde strany dosahují hodnoty „2“ nebo nižší.

\section{Charakteristické osobnostní vlastnosti značek Petra Nečase a Mirka Topolánka}

V následující kapitole se zaměříme na identifikaci nejvýraznějších osobnostních charakteristik bývalého a současného lídra ODS: Mirka Topolánka a Petra Nečase. Intuitivně tušíme, že značky obou lídrů budou značně rozdílné, pohled na data prezentovaná v grafu 2 , respektive tabulce 6 nám pak naši intuitivní úvahu potvrdí.

Oba lídři mají v očích respondentů velmi podobnou image (až na výjimku kategorie bezproblémový, kde výrazně lepších hodnot dosáhl P. Nečas), v dalších kategoriích se oba lídři již rozcházejí. Zatímco v případě osobnostních vlastností značky Petra Nečase jsme hodnoty vyšší než ,3“ zaznamenali v devíti prŕípadech, v prŕípadě Mirka Topolánka byla středová hodnota překročena celkem pětkrát. Větší počet výrazněji vnímaných osobnostních vlastností může být dán také tím, že je předseda vlády často vnímán voliči nejenom jako reprezentant dané strany, ale rovněž celého národa, $\mathrm{v}$ rámci exekutivní pozice je mu také věnována větší 
pozornost médií a má širší pole možností pro prezentaci svých schopností a osobnostních vlastností.

Nejsilněji je respondenty $(\mathrm{N}=109)$ Petr Nečas vnímán jako pracovitý $(3,51)$ a inteligentní $(3,5)$, dále pak jako realistický $(3,21)$, odborný $(3,20)$, čestný $(3,19)$, bezproblémový $(3,19)$, úspěšný $(3,15)$, rodinně založený $(3,14)$ a spolehlivý $(3,11)$. Na druhou stranu Mirek Topolánek je v očích respondentů $(\mathrm{N}=97)$ nadprůměrný v kategoriích sebejistý $(3,84)$ a temperamentní $(3,48)$, dále pak odvážný $(3,4)$, úspěšný $(3,16)$ a mužný $(3,11)$. Povšimněme si, že oba lídři v očích respondentů sdílejí jednu stejnou charakteristiku - jsou vnímáni jako úspěšní.

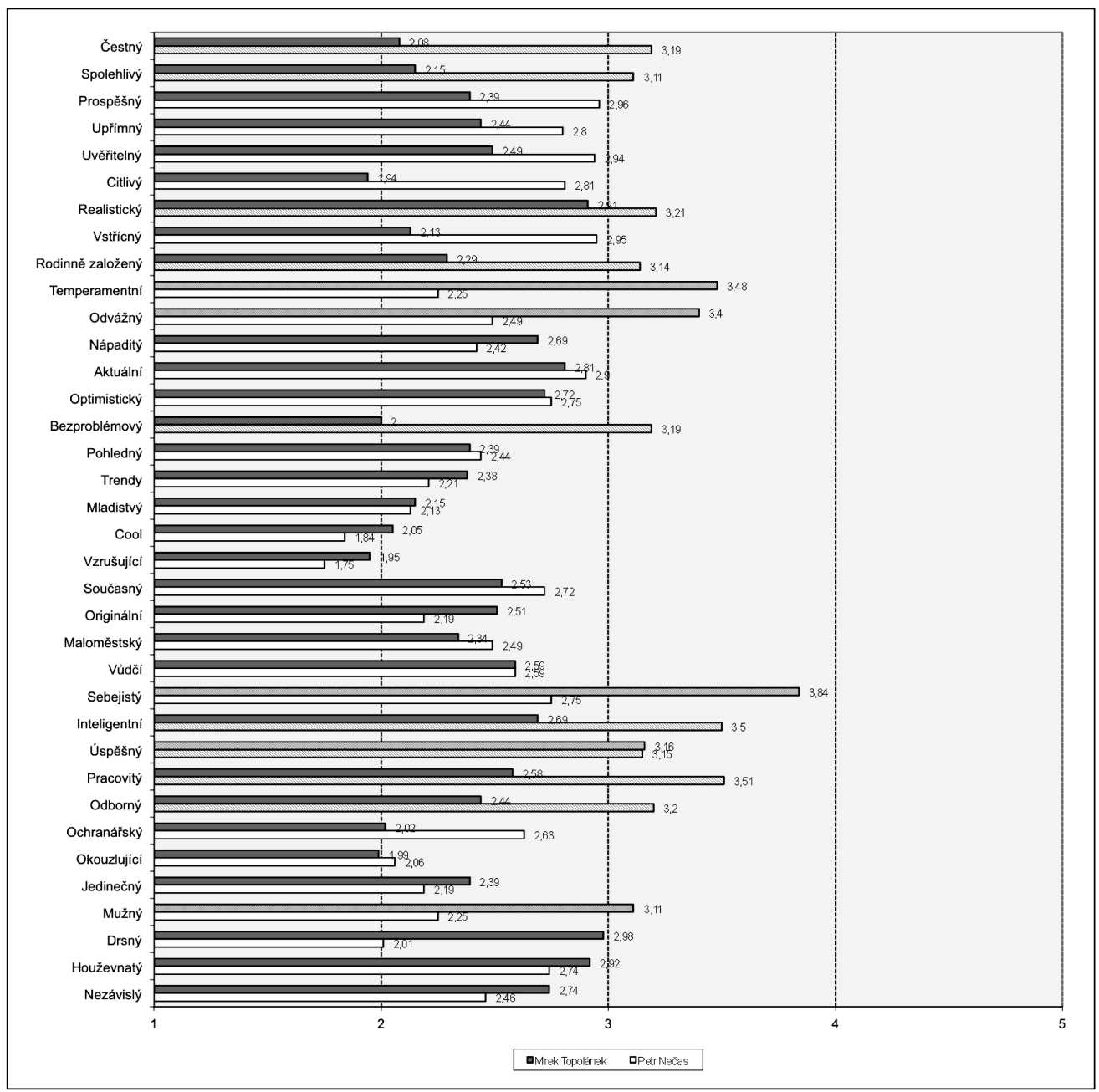

Graf 2: Osobnostní charakteristiky značek Petra Nečase a Mirka Topolánka 
Pokud bychom porovnávali kategorie, ve kterých respondenti hodnotili oba lídry nejhůřre (v tomto případě pod hodnotou ,2“), dospěli bychom k závěru, že Petr Nečas není vnímán jako vzrušujíci $(1,75)$ a cool $(1,84)$. Mirek Topolánek je vnímán jako slabší v kategoriích citlivý $(1,94)$, vzrušujicí $(1,95)$, okouzlujicí $(1,99)$ a bezproblémový $(2,00)$.

Podrobný přehled výsledků jednotlivých osobnostních vlastností nabízí graf 2, respektive tabulka 6.

Poznámka: Zvýrazněné jsou kategorie, kde lídři dosahují hodnoty „3“ nebo vyšší.

Tabulka 6: Osobnostní charakteristiky značek Petra Nečase a Mirka Topolánka

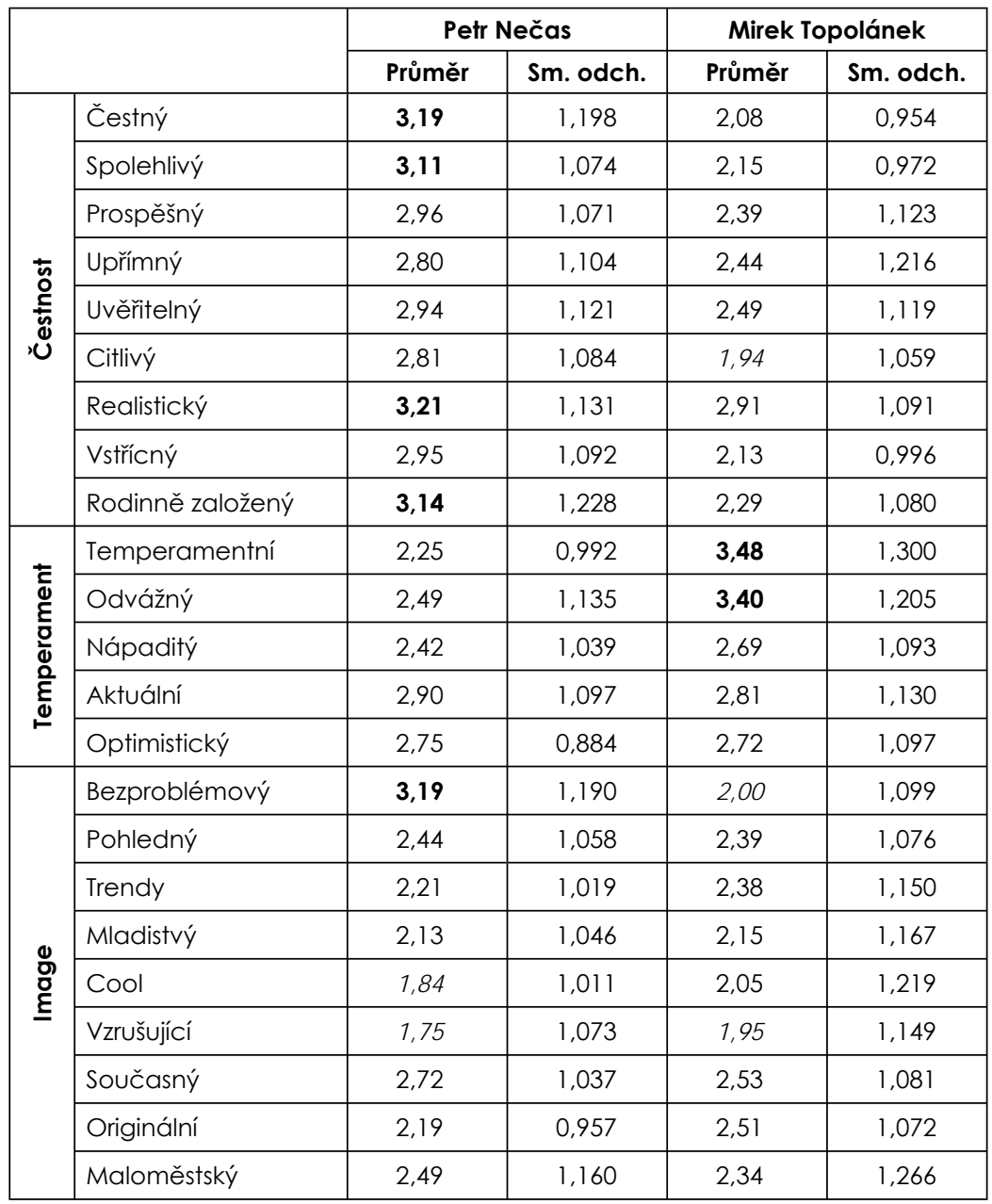


Michal Žižlavský, Otto Eibl: Srovnání osobností politických značek ČSSD, ODS a lídrů těchto stran

\begin{tabular}{|c|c|c|c|c|c|}
\hline & \multicolumn{2}{|c|}{ Petr Nečas } & \multicolumn{2}{|c|}{ Mirek Topolánek } \\
\hline & & Průmèr & Sm. odch. & Průmèr & Sm. odch. \\
\hline \multirow{9}{*}{ 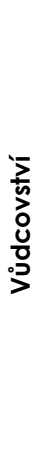 } & Vůdčí & 2,59 & 1,029 & 3,59 & 1,281 \\
\hline & Sebejistý & 2,75 & 1,098 & 3,84 & 1,187 \\
\hline & Inteligentní & 3,50 & 1,176 & 2,69 & 1,064 \\
\hline & Úspěšný & 3,15 & 1,008 & 3,16 & 1,048 \\
\hline & Pracovitý & 3,51 & 1,152 & 2,58 & 0,934 \\
\hline & Odborný & 3,20 & 1,153 & 2,44 & 0,979 \\
\hline & Ochranářský & 2,63 & 0,930 & 2,02 & 0,878 \\
\hline & Okouzlující & 2,06 & 0,998 & 1,99 & 1,132 \\
\hline & Jedinečný & 2,19 & 1,084 & 2,39 & 1,335 \\
\hline \multirow{4}{*}{ 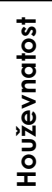 } & Mužný & 2,25 & 1,011 & 3,11 & 1,361 \\
\hline & Drsný & 2,01 & 0,995 & 2,98 & 1,283 \\
\hline & Houževnatý & 2,74 & 1,092 & 2,92 & 1,239 \\
\hline & Nezávislý & 2,46 & 1,118 & 2,74 & 1,175 \\
\hline
\end{tabular}

Poznámka: Tučně zvýrazněné jsou kategorie, kde lídři dosahují hodnoty „,3“ nebo vyšší. Kurzívou zvýrazněné jsou kategorie, kde lídři dosahují hodnoty „2“ nebo nižšśi.

\section{Charakteristické osobnostní vlastnosti značky Bohuslava Sobotky a Jiřího Paroubka}

Podobně jako v případě dvou lídrů ODS lze i mezi bývalým a současným lídrem ČSSD nalézt výrazné rozdíly v osobnostních charakteristikách značek obou politiků. Osobnostní vlastnosti značky B. Sobotky přesáhly středové hodnoty pouze ve čtyřech př́ípadech. Zatímco u současného lídra ODS Petra Nečase se setkáváme se zvýšeným počtem výrazněji vnímaných osobnostních vlastností, u jeho oponenta z ČSSD je tento počet nejnižší ze všech zkoumaných subjektů. To může být následkem mnoha faktorů a vedle možnosti, která se nabízí jako první, tedy nevýrazné osobnosti samotného B. Sobotky, může hrát významnou roli také třeba opoziční role strany nebo fakt, že ze všech zkoumaných politiků B. Sobotka jako jediný nemá doposud zkušenost z pozice předsedy vlády, která, jak už bylo řečeno výše, přitahuje zvýšenou pozornost médií, a dává tak voličům více př́ležitostí vytvořit si jasnější obraz o osobnostní značce politika. B. Sobotku vnímají respondenti $(\mathrm{N}=95)$ nejsilněji jako pracovitého $(3,2)$, inteligentního $(3,09)$, úspěšného $(3,08)$ a rodinně založeného $(3,01)$.

Osobnostní vlastnosti značky J. Paroubka přesáhly středové hodnoty celkem v šesti případech, a jsou tak respondenty $(\mathrm{N}=88)$ zřetelně vnímány silněji než osobnostní vlastnosti značky současného předsedy ČSSD Sobotky. Nejsilněji respondenti vnímají Jiřího Paroubka jako sebejistého $(4,17)$ a vi̊dčího $(3,9)$, dále pak jako odvážného $(3,35)$, maloméstského $(3,33)$, temperamentniho $(3,28)$ a houževnatého $(3,22)$. Za povšimnutí také stojí fakt, že i ve srovnání s ostatními zkoumanými politickými značkami jsou charakteristické osobnostní 
vlastnosti značky Jiřího Paroubka vnímány nejzřetelněji ze všech, kdy hned ve dvou případech (sebejistý a vưdči) dosáhly jejich hodnoty nejvýše naměřených hodnot ze všech měřených vlastností u všech subjektů.

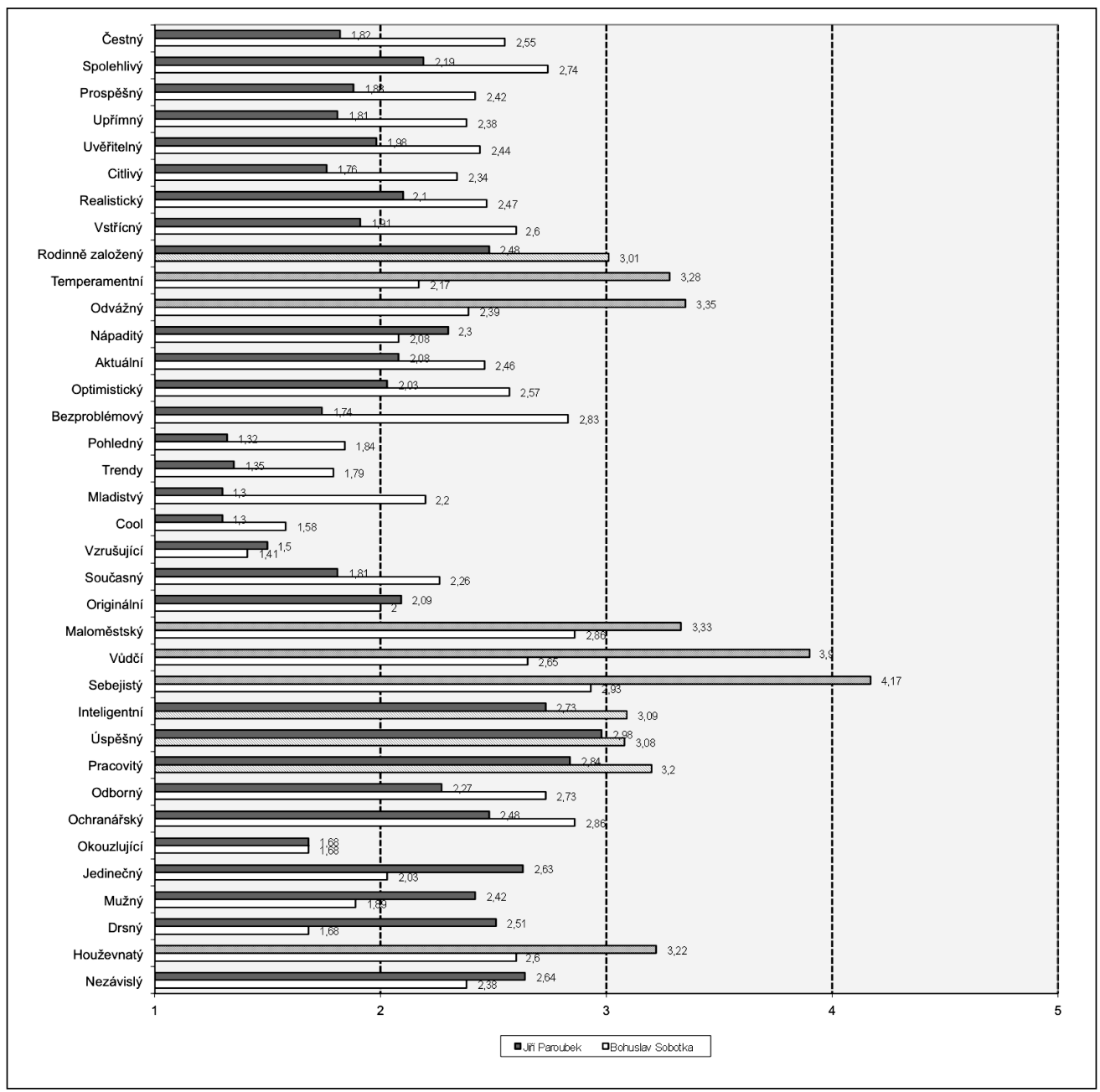

Graf 3: Osobnostní charakteristiky značek Bohuslava Sobotky a Jiř́ho Paroubka

Zajímavé výsledky přináší pohled na „dolní hladinu“ výsledků, tedy na kategorie, v nichž jsou lídři vnímáni jako nejslabší. Zatímco B. Sobotka je jako slabý (hodnota „2“ a nižší) vnímán v osmi prŕípadech - vzrušující $(1,41)$, cool $(1,58)$, okouzlující $(1,68)$, drsný $(1,68)$, trendy $(1,79)$, pohledný $(1,84)$, mužný $(1,89)$ a originální $(2,00)$-, J. Paroubek zaznamenal dokonce 14 výsledků nižších než ,2“. Jde o kategorie mladistvý $(1,3)$, cool $(1,3)$, 
pohledný $(1,32)$, trendy $(1,35)$, vzrušujici $(1,5)$, okouzlujici $(1,68)$, bezproblémový $(1,74)$, citlivý $(1,76)$, upř́mný $(1,81)$, současný $(1,81)$, čestný $(1,82)$, prospěšný $(1,88)$, vstřicný $(1,91)$ a uvěritelný $(1,98)$. Jak je patrné, oba politici z řad ČSSD jsou vnímáni negativněji než jejich konkurenti z ODS, což může být opět dáno vychýlením preferencí respondentů směrem doprava.

Podrobný přehled výsledků jednotlivých osobnostních vlastností nabízí graf 3 a tabulka 7.

Poznámka: Zvýrazněné jsou kategorie, kde lídři dosahují hodnoty „3“ nebo vyšší.

Tabulka 7: Osobnostní charakteristiky značek Bohuslava Sobotky a Jiřího Paroubka

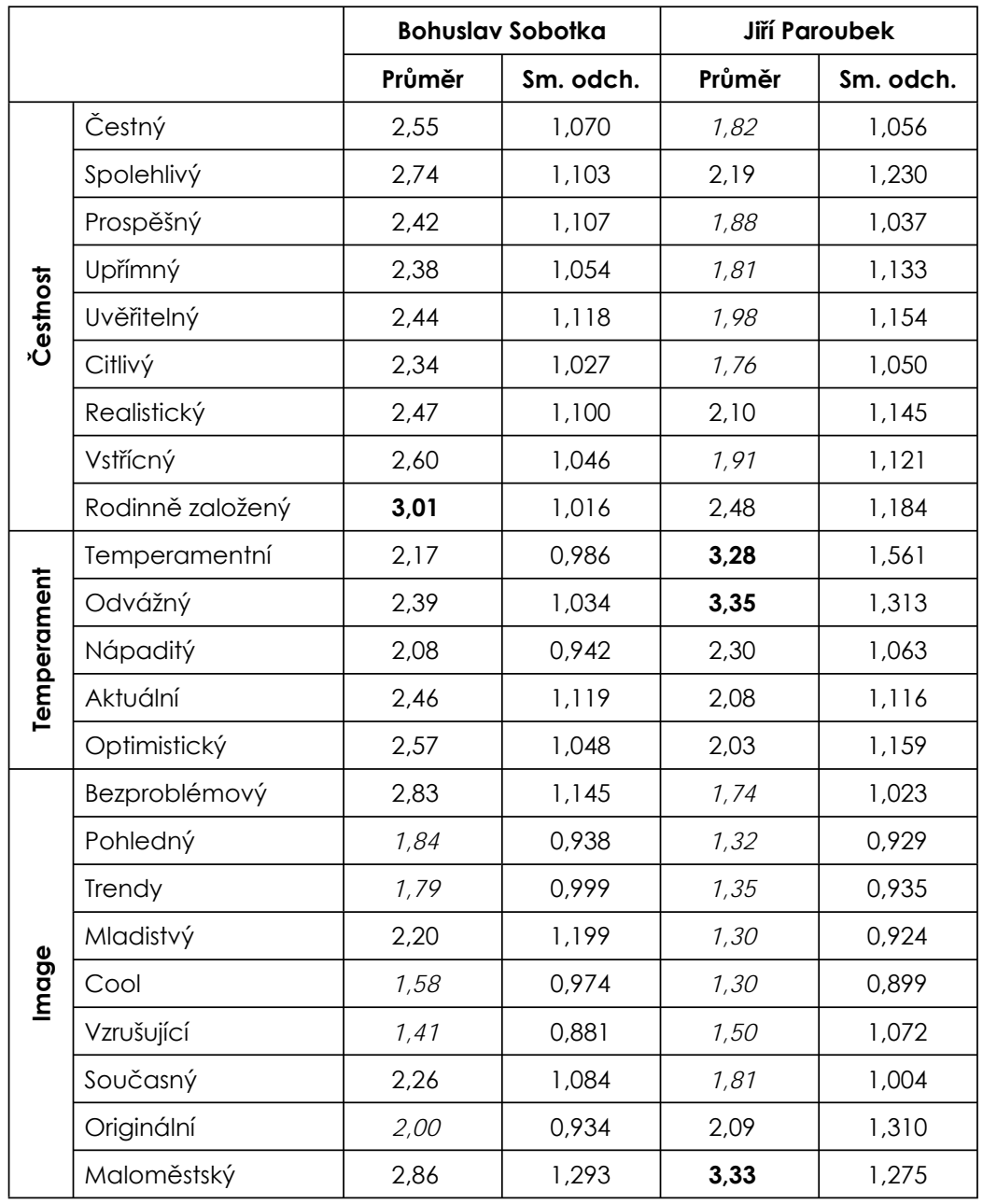




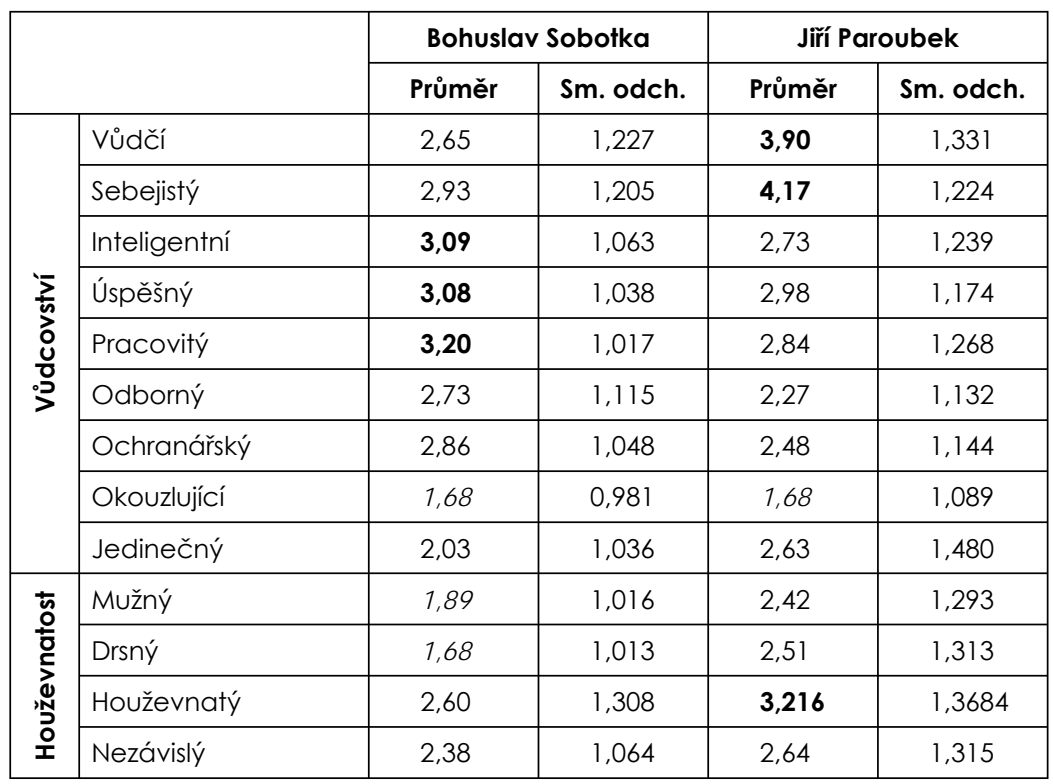

Poznámka: Tučně zvýrazněné jsou kategorie, kde lídři dosahují hodnoty „3“ nebo vyšší. Kurzívou zvýrazněné jsou kategorie, kde lídři dosahují hodnoty „2“ nebo nižší.

\section{Určení odlišnosti osobností značek politických stran a jejich lídrů na úrovni jednotlivých osobnostních vlastností}

V následující části určíme míru odlišnosti osobností značek jednotlivých stran a jejich politických lídrů na úrovni jednotlivých osobnostních vlastností. Jak už bylo uvedeno výše, uděláme to trojím způsobem, a to vypočítáním celkové hodnoty odlišnosti osobnosti značek, průměrné hodnoty odlišnosti jednotlivých osobnostních vlastností a variačního koeficientu jednotlivých osobnostních vlastností.

\section{Odlišnost osobnostních vlastností značky ODS a jejích lídrů}

Všechny tři výše zmíněné hodnoty vypočítané pro podobnost osobnostních vlastností ODS a jejího aktuálního lídra Petra Nečase a osobnostních vlastností ODS s osobnostními vlastnostmi Mirka Topolánka nabízí tabulka 8. Kompletní výpočet rozdílů pro jednotlivé osobnostní vlastnosti nabízí tabulka umístněná pro svou velikost jako př́loha 1 . 
Michal Žižlavský, Otto Eibl: Srovnání osobností politických značek ČSSD, ODS a lídrů těchto stran

Tabulka 8: Odlišnost osobnostních vlastností značek ODS, Petra Nečase a Mirka Topolánka

\begin{tabular}{|l|c|c|}
\hline & Petr Nečas & Mirek Topolánek \\
\hline Směrodatná odchylka & 0,26 & 0,15 \\
\hline Celková odlišnost & 12,87 & 8,56 \\
\hline Průměrná odlišnost & 0,36 & 0,24 \\
\hline Variační koeficient & 0,725 & 0,639 \\
\hline
\end{tabular}

Z tabulky je zřejmé, že se osobnost značky ODS mnohem více podobá osobnosti značky jejího bývalého lídra Mirka Topolánka. Dokazuje nám to jak hodnota celkové odlišnosti, která je vyšší u Petra Nečase, a to oproti M. Topolánkovi dokonce o 4,31, tak hodnota průměrné odlišnosti jednotlivých osobnostních vlastností, které se od osobnostních vlastností značky ODS liší u Mirka Topolánka v průměru pouze o 0,24, zatímco u Petra Nečase o 0,36. Vyšší hodnotu než u Mirka Topolánka vykazuje u Petra Nečase také variační koeficient jednotlivých rozdílů osobnostních vlastností, který značí větší odlišnosti v rozložení osobnostních vlastností Petra Nečase vǔči ODS. Tím došlo k vyvrácení předpokladu, že osobnost značky Petra Nečase se bude osobnosti značky ODS podobat více než osobnost značky Mirka Topolánka.

\section{Odlišnost osobnostních vlastností značky ČSSD a jejích lídrů}

Hodnoty odlišnosti vypočítané pro ČSSD a její lídry Bohuslava Sobotku a Jiřího Paroubka nabízí tabulka 9. Kompletní výpočet rozdílů pro jednotlivé osobnostní vlastnosti nabízí tabulka umístněná pro jako př́loha 2.

Tabulka 9: Odlišnost osobnostních vlastností značek ČSSD, Bohuslava Sobotky a Jirího Paroubka

\begin{tabular}{|l|c|c|}
\hline & Bohuslav Sobotka & Jiří Paroubek \\
\hline Směrodatná odchylka & 0,22 & 0,23 \\
\hline Celková odlišnost & 11,42 & 12,1 \\
\hline Prưměrná odlišnost & 0,32 & 0,34 \\
\hline Variační koeficient & 0,684 & 0,672 \\
\hline
\end{tabular}

Z tabulky 6 poměrně překvapivě vyplývá, že se osobnost značky ČSSD podobá o něco více osobnosti značky jejího současného lídra Bohuslava Sobotky než jejího bývalého lídra Jiřího Paroubka. Tím tak došlo k vyvrácení předpokladu, který jsme si stanovili na základě nejčastějšího zmínění Jiřího Paroubka, jakožto prvního politika, který se respondentům vybaví ve spojitosti s ČSSD. Rozdíl ve vzájemném srovnání míry podobnosti těchto dvou lídrů vůči ČSSD ovšem není tak znatelný, jak tomu bylo u lídrů ODS. Dokonce by se dal označit za minimální. Zároveň se ovšem osobnosti značky obou lídrů ČSSD podobají značce 
jejich strany méně, než tomu bylo u ODS a Mirka Topolánka, ale zato více, než tomu bylo u ODS a Petra Nečase.

Důležité je také poukázat na to, že ačkoliv se osobnost značky Bohuslava Sobotky liší od osobnosti značky ČSSD méně než osobnost značky Jiřího Paroubka v rámci hodnoty celkové odlišnosti a průměrné odlišnosti jednotlivých vlastností, o něco nižší hodnotu naopak vykazuje u Jiřího Paroubka variační koeficient. To implikuje, že rozložení jednotlivých vnímaných osobnostních vlastností je tak u osobnosti značky Jiřího Paroubka podobnější osobnosti značky ČSSD než u Bohuslava Sobotky.

\section{Určení odlišnosti osobností značek politických stran a jejich lídrů na úrovni osobnostních dimenzí}

V následující části určíme míru odlišnosti osobností značek jednotlivých stran a jejich politických lídrů na úrovni osobnostních dimenzí. ${ }^{8}$ Stejně jako v předchozí kapitole $\mathrm{k}$ tomu využijeme celkové hodnoty odlišnosti osobnosti značek, průměrné hodnoty odlišnosti jednotlivých osobnostních vlastností a variačního koeficientu rozdílů jednotlivých osobnostních vlastností. Nižší počet veličin nám navíc umožní vyjádřit odlišnosti také graficky pomocí paprskových grafů.

\section{Odlišnost osobnostních dimenzí značky ODS a jejích lídrů}

Hodnoty odlišnosti na úrovni osobnostních dimenzí značky vypočítané pro ODS a její lídry Petra Nečase a Mirka Topolánka nabízí tabulka 10.

Tabulka 10: Odlišnost osobnostních dimenzí značek ODS, Petra Nečase a Mirka Topolánka

\begin{tabular}{|l|c|c|c|c|c|}
\hline Dimenze & ODS & Nečas & Rozdíly & Topolánek & Rozdíly \\
\hline Čestnost & 2,49 & 3,01 & 0,52 & 2,31 & 0,18 \\
\hline Temperament & 2,81 & 2,56 & 0,25 & 3,03 & 0,22 \\
\hline Image & 2,39 & 2,33 & 0,06 & 2,25 & 0,14 \\
\hline Vůdcovství & 2,76 & 2,84 & 0,08 & 2,74 & 0,02 \\
\hline Houževnatost & 2,72 & 2,36 & 0,36 & 2,94 & 0,22 \\
\hline Směrodatná odchylka & 0,18 & 0,3 & $\mathbf{0 , 1 9}$ & 0,36 & $\mathbf{0 , 0 8}$ \\
\hline Celková odlišnost & & & $\mathbf{1 , 2 7}$ & & $\mathbf{0 , 7 8}$ \\
\hline Průměrná odlišnost & & & $\mathbf{0 , 2 5 4}$ & & $\mathbf{0 , 1 5 6}$ \\
\hline Variační koeficient & & & $\mathbf{0 , 6 8 1}$ & & $\mathbf{0 , 4 7 5}$ \\
\hline
\end{tabular}

Tabulka pro úroveň osobnostních dimenzí ODS potvrzuje to, co se nám podařilo zjistit už na úrovni jednotlivých osobnostních vlastností. Osobnost značky ODS se mnohem

$8 \quad$ Hodnoty jednotlivých dimenzí jsou vypočítány jako průměr hodnot pro jednotlivé osobnostní vlastnosti, které pod danou dimenzi spadají. 
více podobá osobnosti značky jejího bývalého lídra Mirka Topolánka než jejího současného lídra Petra Nečase, a to opět u všech použitých indikátorů. Prostorové vyjádření těchto odlišností umožňuje graf 7.



Graf 7: Srovnání osobnostních dimenzí ODS, Petra Nečase a Mirka Topolánka

Graf 7 nám zrretelně prokazuje blízkost osobnosti značek ODS a Mirka Topolánka. Prostorové rozložení jejich osobnostních dimenzí je takřka shodné a odlišuje se pouze v několika detailech. Oproti tomu prostorové rozložení osobnostních dimenzí značky Petra Nečase se v porovnání s ODS v několika bodech značně rozchází. Těmito body jsou především dimenze čestnost, ve které Petr Nečas dosahuje výrazně vyšších hodnot než ODS, a dále dimenze houževnatost, ve které Petr Nečas oproti ODS naopak znatelně ztrácí. Zřetelné jsou také jeho nižší hodnoty u dimenze temperament.

\section{Odlišnost osobnostních dimenzí značky ČSSD a jejích lídrů}

Hodnoty odlišnosti na úrovni osobnostních dimenzí značky vypočítané pro ČSSD a její lídry Bohuslava Sobotku a Jiř́ho Paroubka nabízí tabulka 11.

Tabulka 11: Odlišnost osobnostních dimenzí značek ČSSD, Bohuslava Sobotky a Jiřího Paroubka

\begin{tabular}{|l|c|c|c|c|c|}
\hline Dimenze & ČSSD & Sobotka & Rozdíly & Paroubek & Rozdíly \\
\hline Čestnost & 2,33 & 2,55 & 0,22 & 1,91 & 0,42 \\
\hline Temperament & 2,59 & 2,33 & 0,26 & 2,6 & 0,01 \\
\hline Image & 1,96 & 2,09 & 0,13 & 1,74 & 0,22 \\
\hline Vůdcovství & 2,64 & 2,64 & 0 & 2,85 & 0,21 \\
\hline Houževnatost & 2,50 & 2,14 & 0,36 & 2,69 & 0,19 \\
\hline Směrodatná odchylka & 0,27 & 0,24 & $\mathbf{0 , 1 4}$ & 0,5 & $\mathbf{0 , 1 5}$ \\
\hline Celková odlišnost & & & $\mathbf{0 , 9 7}$ & & $\mathbf{1 , 0 5}$ \\
\hline Průměrná odlišnost & & & $\mathbf{0 , 1 9 4}$ & & $\mathbf{0 , 2 1}$ \\
\hline Variační koeficient & & & $\mathbf{0 , 6 2 8}$ & & $\mathbf{0 , 6 2 2}$ \\
\hline
\end{tabular}


I tabulka pro úroveň osobnostních dimenzí ČSSD potvrzuje to, co se nám podařilo zjistit už na úrovni jednotlivých osobnostních vlastností. Osobnost značky ČSSD se více podobá osobnosti značky jejího současného lídra Bohuslava Sobotky než jejího bývalého lídra Jiřího Paroubka, jehož osobnost značky ovšem vykazuje nižší variační koeficient. Rozdíly mezi politiky jsou ale i v tomto případě pouze minimální, na rozdíl od lídrů ODS. Zároveň ani tentokrát nedosahuje žádný z lídrů ČSSD takovou blízkost osobnosti své značky s osobností značky své strany, jako tomu je u Mirka Topolánka a ODS. Prostorové vyjádření odlišností osobností značky ČSSD a jejích lídrů na úrovni osobnostních dimenzí vyjadřuje graf 8 .

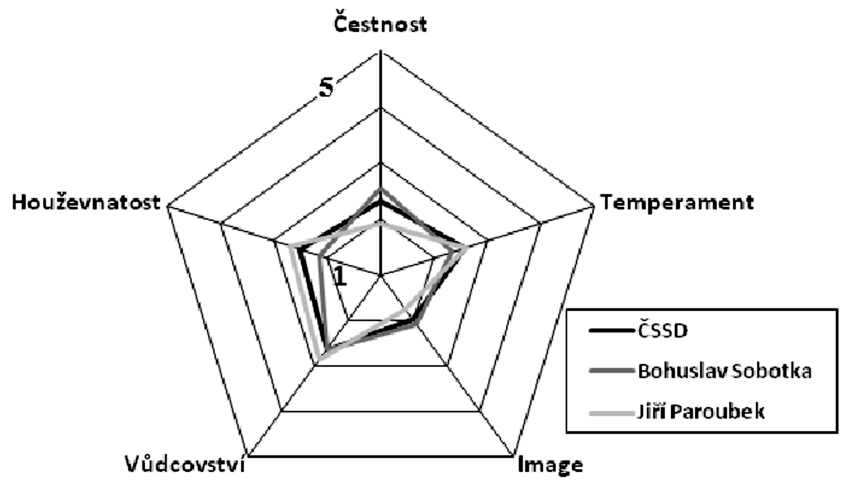

Graf 8: Srovnání osobnostních dimenzí ČSSD, Bohuslava Sobotky a Jiřího Paroubka

Graf 8 prokazuje větší blízkost osobností značek ČSSD a Bohuslava Sobotky. Osobnost značky Bohuslava Sobotky se s osobností značky ČSSD překrývá v dimenzích temperament, image a vůdcovství, vyšší hodnoty ovšem prokazuje u dimenze čestnost a naopak výrazně nižší u dimenze houževnatost. Oproti tomu osobnost značky Jiř́ho Paroubka se osobnosti značky ČSSD velmi blíží v dimenzích temperament, houževnatost a vůdcovství, znatelně nižší hodnoty ale prokazuje u dimenzí image a - především - čestnost. Dalo by se tedy říct, že osobnosti značek obou lídrů se osobnosti značky ČSSD poměrně podobají, existují mezi nimi ovšem výrazné odlišnosti $\mathrm{v}$ rámci některých osobnostních dimenzí. Ani u jednoho z těchto dvou lídrů ovšem nedochází k takové míře podobnosti jeho osobnostních vlastností s osobnostními vlastnostmi jeho strany, jako tomu je u Mirka Topolánka a ODS. Na základě uvedených výsledků tak můžeme konstatovat, že zatímco osobnost značky Mirka Topolánka do určité míry ztělesňuje, co značka ODS pro respondenty představuje, u lídrů ČSSD tomu tak je pouze $\mathrm{v}$ rámci některých osobnostních dimenzí.

\section{Srovnání osobností značek ODS, Petra Nečase a Mirka Topolánka s osobnostními značkami ČSSD, Bohuslava Sobotky a Jiř́iho Paroubka}

Velmi zajímavé zjištění nabízí také srovnání jednotlivých soupeřících politických subjektů mezi sebou navzájem. Pro srovnání těchto subjektů použijeme úroveň osobnostních 
dimenzí a jako nástroj využijeme opět paprskové grafy, které ukazují prostorové rozložení hodnot jednotlivých osobnostních dimenzí

\subsection{Srovnání Osobnostních dimenzí ODS a ČSSD}

Srovnání osobnostních dimenzí ODS a ČSSD uvádí graf 9.

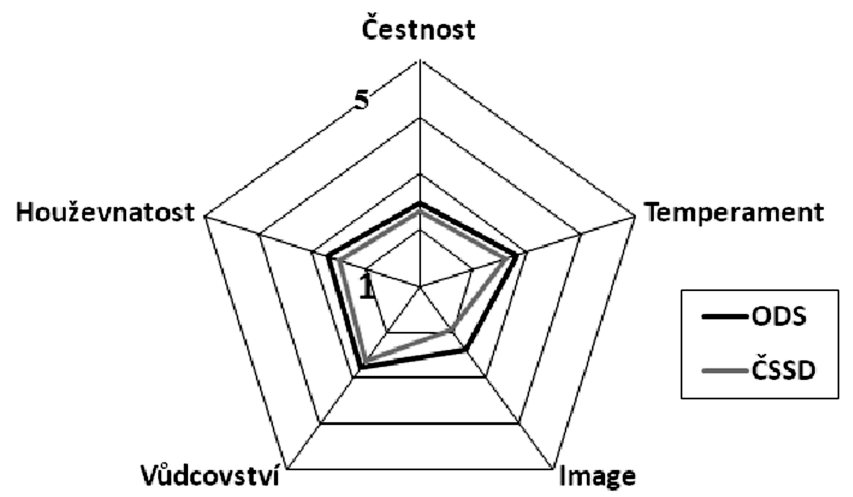

Graf 9: Srovnání Osobnostních dimenzí ODS a ČSSD

Graf 9 nabízí poměrně nečekané zjištění. Vyplývá z něj, že rozložení osobnostních dimenzí ODS a ČSSD je respondenty vnímáno prakticky totožně, s tím rozdílem, že hodnoty dimenzí ODS jsou vnímány silněji než hodnoty dimenzí ČSSD. Jediný znatelnější rozdíl vidíme u dimenze image, ve které ČSSD vykazuje výrazně nižší výsledek. V rámci celkového rozložení ostatních dimenzí ale značka ČSSD značku ODS téměř dokonale kopíruje.

\section{Srovnání osobnostních dimenzí Petra Nečase a Bohuslava Sobotky}

Srovnání osobnostních dimenzí Petra Nečase a Bohuslava Sobotky nabízí graf 10.

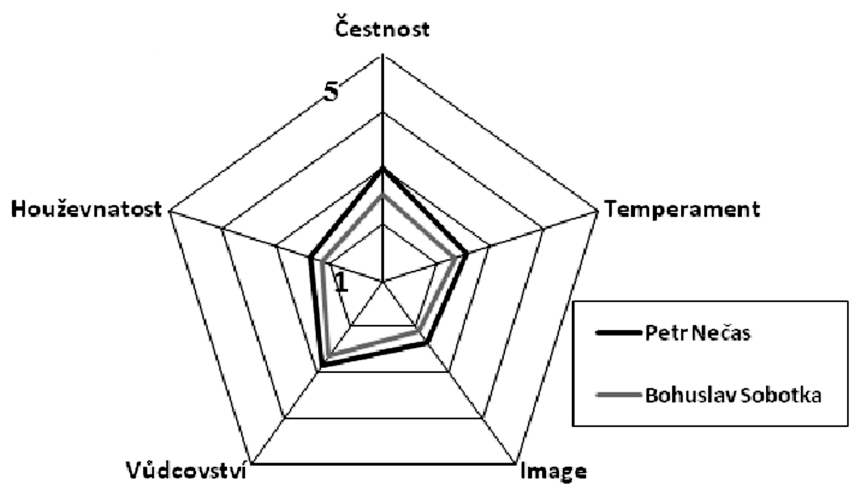

Graf 10: Srovnání osobnostních dimenzí Petra Nečase a Bohuslava Sobotky 
I graf 10 překvapivě prokazuje velkou podobnost mezi rozložením osobnostních dimenzí značky Petra Nečase a Bohuslava Sobotky, s tím, že stejně jako v př́padě ODS a ČSSD jsou hodnoty osobnostních dimenzí u předsedy ČSSD obecně nižní než hodnoty osobnostních dimenzí předsedy ODS. Jedinou výraznou odlišnost vidíme v případě dimenze čestnost, př́ípadně také u dimenze houževnatost, kdy respondenti vnímají tyto dimenze zřetelně silněji u Petra Nečase, byt' u dimenze houževnatost ovšem ne v takové míře.

\section{Srovnání osobnostních dimenzí Mirka Topolánka a Jirího Paroubka}

Srovnání osobnostních dimenzí Mirka Topolánka a Jiřího Paroubka nabízí graf 11.

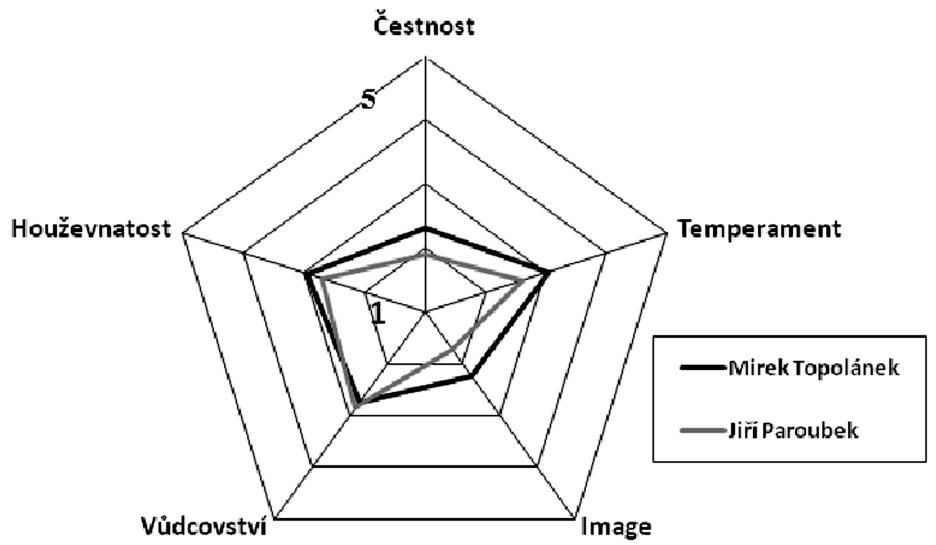

Graf 11: Srovnání osobnostních dimenzí Mirka Topolánka a Jiřího Paroubka

I třetí srovnání překvapivě prokazuje blízkost rozložení osobnostních dimenzí dvou zástupců opačných stran politického spektra, tentokrát Mirka Topolánka a Jiřího Paroubka. Ty sice nevykazují tak výraznou blízkost, jako tomu bylo u předchozích subjektů, přesto je celková podobnost prostorového rozložení jejich osobnostních dimenzí jasně viditelná. Podobně jako u předchozích subjektů jsou dimenze zástupce ODS vnímány silněji než zástupce ČSSD, výjimkou je v tomto případě dimenze vůdcovství, ve které Jiří Paroubek vykazuje těsně vyšší hodnoty než Mirek Topolánek. Oproti němu ale disponuje výrazně nižšími hodnotami především u dimenze image, ale také u dimenzí čestnost a temperament.

\section{Závěr}

$\mathrm{V}$ rámci výzkumu bylo využito konceptu osobnosti značky pro testování hypotéz vycházejících z předpokladu, že vlastnosti značky lídra strany se přenášejí na značku strany samotné. Osobnosti značek byly testovány u českých politických stran ČSSD a ODS a jejich lídrů. Hypotézy práce byly stanoveny následovně: Hypotéza 1: „Osobnosti značek ČSSD a ODS se podobají osobnostem značek svých lídrư“; a hypotéza 2: „Osobnosti značek 
bývalých lídrů ČSSD a ODS se podobají osobnostem značek ČSSD a ODS více než osobnosti značek jejich současných lídrů.“

Ke srovnání mezi těmito entitami došlo na dvou úrovních - na úrovni jednotlivých osobnostních vlastností a poté na úrovni osobnostních dimenzí. Obě úrovně přitom nabídly stejné výsledky. Z těch vyplývá, že osobnosti značky ODS se více podobá osobnost značky Mirka Topolánka, zatímco mezi osobností značky strany a osobností značky Petra Nečase už panuje podobnost daleko menší. Tento stav potvrdily všechny použité metody. V př́padě ČSSD je tento stav opačný. Osobnosti značky této strany je více podobná osobnost značky strany jejího současného předsedy Bohuslava Sobotky. Rozdíl mezi hodnotami odlišnosti osobnosti značky Bohuslava Sobotky a Jiř́ho Paroubka od osobnosti značky ČSSD je však prakticky minimální, jediná hodnota, ve které osobnost značky Jiří Paroubka vykázala větší podobnost s osobností značky ČSSD než Bohuslav Sobotka, byla hodnota variačního koeficientu, vyjadřující v tomto případě podobnost celkového rozložení jednotlivých osobnostních vlastností. Je nicméně nutné zdůraznit, že ani jeden z lídrů ČSSD nevykazuje takovou podobnost osobnosti své značky s osobností své strany jako Mirek Topolánek s ODS. Na druhou stranu je ale podobnost obou lídrů ČSSD s jejich stranou vyšší než podobnost ODS a Petra Nečase.

$\mathrm{S}$ vědomím a ohledem na limity výzkumu a interpretaci jeho výsledků, které jsme diskutovali výše, můžeme první hypotézu považovat za platnou. Zřetelné je to především u Mirka Topolánka. U Bohuslava Sobotky, Jiřího Paroubka a nejvýrazněji pak u Petra Nečase je už tato podobnost nižší.

Co se týče druhé hypotézy, musíme ji v tomto př́padě odmítnout, jelikož se potvrdila pouze z poloviny, a to u vztahu podobnosti mezi osobností značek Mirka Topolánka a ODS. $\mathrm{Na}$ základě uvedených výsledků poté můžeme konstatovat, že zatímco osobnost značky Mirka Topolánka do určité míry ztělesňuje, co značka ODS pro respondenty představuje, u lídrů ČSSD a u Petra Nečase je tomu tak pouze v rámci některých osobnostních dimenzí.

Pozitivně se můžeme vyjádřit $\mathrm{k}$ samotnému použití metody osobnosti značky. I na poměrně limitovaném vzorku respondentů se prokázala jako schopná produkovat reliabilní výsledky disponující značným výpovědním potenciálem. Při použití v delším časovém rámci navíc představuje vhodný nástroj pro odhalení mechanismu př́ípadného přenosu osobnostních vlastností mezi politickými stranami a jejich politiky (např́klad v rámci re-brandingu), a je tak určitě vhodné a prrínosné v jejím testování dále pokračovat.

\section{Literatura}

AAKER, Jennifer. Dimensions of Brand Personality. Journal of Marketing Research, 1997, roč. II, č. 34, s. 347-56. ISSN 0022-2437.

DISMAN, Miroslav. Jak se vyrábi sociologická znalost: přiručka pro uživatele. Praha: Karolinum, 2000. 374 s. ISBN 8024601397.

EIBL, Otto; HAVLÍK, Vlastimil; KYLOUŠEK, Jakub; PINK, Michal. Krajské volby 2008. Brno: CDK, 2009. 175 s. ISBN 9788073251871.

FRENCH, Adam; SMITH, Ian Gareth. Measuring Political Brand Equity: A Consumer Approach [online]. Dokument prezentovaný na 5th International Conference on Political Marketing, březen 
2008, Manchester [cit 15. 5. 2011]. Dostupné na www: <www.mtq.sagepub.com/content/9/2/209. full.pdf>

JAABAR, Zeenat. Impact of Corporate Visual Identity on Customer-based Brand Equity [online]. Dokument prezentovaný na Brunel Bussines School Doctoral Symposium, březen 2010, Londýn [cit 15. 5. 2011]. Dostupné na www: < www.brunel.ac.uk/329/BBS\%20documents/PhD\%20Doctoral\%20 Symposium\%2010/ZeenatJabbar.pdf>

KELLER, Kevin, Lane. Building, Measuring and Managing Brand Equity. New Jersey: Prentice Hall, 2003. 411 s. ISBN-13 9780130411501.

SHERRINGTON, Mark. Added Value: The Alchemy of Brand-Led Growth. Basingstoke: Palgrave Macmillan, 2003. 208 s. ISBN-139780230513488.

SMITH, Ian Gareth. Conceptualizing and Testing Brand Personalities in British Politics. Journal of Political Marketing, 2009, roč. III, č. 8, s. 209-232. ISSN: 1537-7857.

SOUKUP, Petr. Čím větší, tím lepši (aneb mýty o reliabilitě). Socioweb, 2006, č. 7 [online]. [Cit 15. 5. 2011.] Dostupné na www: $<$ www.socioweb.cz/index.php?disp=teorie\&shw=242\&lst=112>.

TOMZ, Michael; SNIDERMAN, Paul. Brand Names and the Organisation of Mass Belief Systems [online]. Stanford University, 2005 [cit 15. 5. 2011]. Dostupné na www: <www.stanford.edu/ tomz/ working/TomzSniderman2005.pdf>

WOOD, Lisa. Brands and Brand Equity: Definition and Management. Management Decision, 2000, roč. IX, č. 38, s. 662-669. ISBN-13: 9789524880114.

\section{Autoři}

Michal Žižlavský je absolventem magisterského studijního programu politologie se specializací na volební studia a politický marketing na Fakultě sociálních studií Masarykovy univerzity. Odborně se zaměřuje na problematiku brandingu.

Kontakt: michal.zizlavsky@gmail.com

Otto Eibl působí jako odborný asistent na Katedře politologie Fakulty sociálních studií Masarykovy univerzity, kde vyučuje kurzy s tematikou politické komunikace a politického marketingu. Do těchto oblastí také soustředí svůj badatelský zájem. Zkoumá tedy zejména politické značky, jejich obsahy a procesy, kterými jsou utvářeny a udržovány, umistování politických témat $\mathrm{v}$ politickém prostoru a komunikační a marketingové strategie politických stran $\mathrm{v}$ rámci předvolebního období i mimo ně. Pro přehled publikací viz $<w w w . b i t . l y /$ eibl-publikace>.

Kontakt: eibl@fss.muni.cz 
Michal Žižlavský, Otto Eibl: Srovnání osobností politických značek ČSSD, ODS a lídrů těchto stran

Prílohy

Príloha 1: Odlišnost osobnostních vlastností značek ODS, Petra Nečase a Mirka Topolánka - kompletní výpočty

\begin{tabular}{|c|c|c|c|c|c|}
\hline Osobnostní vlastnost & ODS & Petr Nečas & Rozdíl ODS x PN & Mirek Topolánek & Rozdíl ODS x MT \\
\hline Čestný & 2,32 & 3,19 & 0,87 & 2,08 & 0,24 \\
\hline Spolehlivý & 2,54 & 3,11 & 0,57 & 2,15 & 0,39 \\
\hline Prospěšný & 2,78 & 2,96 & 0,33 & 2,39 & 0,39 \\
\hline Upřímný & 2,17 & 2,8 & 0,63 & 2,44 & 0,27 \\
\hline Uvěřitelný & 2,56 & 2,94 & 0,38 & 2,49 & 0,07 \\
\hline Citlivý & 2,12 & 2,81 & 0,69 & 1,94 & 0,18 \\
\hline Realistický & 3,05 & 3,21 & 0,16 & 2,91 & 0,14 \\
\hline Vstřícný & 2,54 & 2,95 & 0,41 & 2,13 & 0,41 \\
\hline Rodinně založený & 2,34 & 3,14 & 0,8 & 2,29 & 0,05 \\
\hline Temperamentní & 2,85 & 2,25 & 0,6 & 3,48 & 0,63 \\
\hline Odvážný & 2,94 & 2,49 & 0,45 & 3,4 & 0,46 \\
\hline Nápaditý & 2,59 & 2,42 & 0,17 & 2,69 & 0,1 \\
\hline Aktuální & 2,98 & 2,9 & 0,08 & 2,81 & 0,17 \\
\hline Optimistický & 2,67 & 2,75 & 0,08 & 2,72 & 0,05 \\
\hline Bezproblémový & 2,22 & 3,19 & 0,97 & 2 & 0,22 \\
\hline Pohledný & 2,53 & 2,44 & 0,09 & 2,39 & 0,14 \\
\hline Trendy & 2,52 & 2,31 & 0,21 & 2,38 & 0,14 \\
\hline Mladistvý & 2,45 & 2,19 & 0,26 & 2,15 & 0,3 \\
\hline Cool & 2,17 & 2,25 & 0,08 & 2,05 & 0,12 \\
\hline Vzrušující & 2,12 & 2,01 & 0,11 & 1,95 & 0,17 \\
\hline Současný & 2,85 & 2,72 & 0,13 & 2,53 & 0,32 \\
\hline Originální & 2,32 & 2,19 & 0,13 & 2,51 & 0,19 \\
\hline Maloměstský & 2,31 & 2,49 & 0,18 & 2,34 & 0,03 \\
\hline Vůdčí & 3,07 & 2,59 & 0,48 & 2,59 & 0,48 \\
\hline Sebejistý & 3,44 & 2,75 & 0,69 & 3,84 & 0,4 \\
\hline Inteligentní & 3 & 3,5 & 0,5 & 2,69 & 0,31 \\
\hline
\end{tabular}




\begin{tabular}{|l|c|c|c|c|c|}
\hline Osobnostní vlastnost & ODS & Petr Nečas & Rozdíl ODS x PN & Mirek Topolánek & Rozdíl ODS x MT \\
\hline Úspěšný & 3,11 & 3,15 & 0,04 & 3,16 & 0,05 \\
\hline Pracovitý & 2,88 & 3,51 & 0,63 & 2,58 & 0,3 \\
\hline Odborný & 2,88 & 3,2 & 0,32 & 2,44 & 0,44 \\
\hline Ochranářský & 2,31 & 2,63 & 0,32 & 2,02 & 0,29 \\
\hline Okouzlující & 1,98 & 2,06 & 0,08 & 1,99 & 0,01 \\
\hline Jedinečný & 2,17 & 2,19 & 0,02 & 2,39 & 0,22 \\
\hline Mužný & 2,68 & 2,25 & 0,43 & 3,11 & 0,43 \\
\hline Drsný & 2,65 & 2,01 & 0,64 & 2,98 & 0,33 \\
\hline Houževnatý & 2,84 & 2,74 & 0,1 & 2,92 & 0,08 \\
\hline Nezávislý & $\mathbf{2 , 7}$ & $\mathbf{2 , 4 6}$ & $\mathbf{0 , 2 4}$ & $\mathbf{2 , 7 4}$ & $\mathbf{0 , 0 4}$ \\
\hline Směrodatná odchylka & $\mathbf{0 , 4 9}$ & $\mathbf{0 , 4 2}$ & $\mathbf{0 , 2 6}$ & $\mathbf{0 , 4 6}$ & $\mathbf{0 , 1 5 5}$ \\
\hline Celková odlišnost & & & $\mathbf{1 2 , 8 7}$ & $\mathbf{0 , 3 6}$ & $\mathbf{0 , 7 2 5}$ \\
\hline Průměrná odlišnost & & & & & $\mathbf{0 , 6 3 9}$ \\
\hline Variační koeficient & & & & & \\
\hline
\end{tabular}

Přiloha 2: Odlišnost osobnostních vlastností značek ČSSD, Bohuslava Sobotky a Jiřího Paroubka - kompletní výpočty

\begin{tabular}{|l|c|c|c|c|c|}
\hline Osobnostní vlastnost & ČsSD & $\begin{array}{c}\text { Bohuslav } \\
\text { Sobotka }\end{array}$ & Rozdíl ČSSD x BS & Jiří Paroubek & Rozdíl ČSSD x JP \\
\hline Čestný & 2,1 & 2,55 & 0,45 & 1,82 & 0,28 \\
\hline Spolehlivý & 2,25 & 2,74 & 0,49 & 2,19 & 0,06 \\
\hline Prospěšný & 2,29 & 2,42 & 0,13 & 1,88 & 0,41 \\
\hline Upř́mný & 2,13 & 2,38 & 0,25 & 1,81 & 0,32 \\
\hline Uvěřitelný & 2,11 & 2,44 & 0,33 & 1,98 & 0,13 \\
\hline Citlivý & 2,51 & 2,34 & 0,17 & 1,76 & 0,75 \\
\hline Realistický & 1,99 & 2,47 & 0,48 & 2,1 & 0,11 \\
\hline Vstř́cný & 2,44 & 2,6 & 0,16 & 1,91 & 0,53 \\
\hline Rodinně založený & 3,18 & 3,01 & 0,17 & 2,48 & 0,7 \\
\hline Temperamentní & 2,79 & 2,17 & 0,62 & 3,28 & 0,49 \\
\hline Odvážný & 2,78 & 2,39 & 0,39 & 3,35 & 0,57 \\
\hline Nápaditý & 2,32 & 2,08 & 0,24 & 2,3 & 0,02 \\
\hline
\end{tabular}


Michal Žižlavský, Otto Eibl: Srovnání osobností politických značek ČSSD, ODS a lídrů těchto stran

\begin{tabular}{|c|c|c|c|c|c|}
\hline Osobnostní vlastnost & ČSSD & $\begin{array}{l}\text { Bohuslav } \\
\text { Sobotka }\end{array}$ & Rozdíl ČSSD x BS & Jirí Paroubek & Rozdíl ČSSD x JP \\
\hline Aktuální & 2,41 & 2,46 & 0,05 & 2,08 & 0,33 \\
\hline Optimistický & 2,64 & 2,57 & 0,07 & 2,03 & 0,61 \\
\hline Bezproblémový & 2,31 & 2,83 & 0,52 & 1,74 & 0,57 \\
\hline Pohledný & 1,76 & 1,84 & 0,08 & 1,32 & 0,44 \\
\hline Trendy & 1,71 & 1,79 & 0,08 & 1,35 & 0,36 \\
\hline Mladistvý & 1,71 & 2,2 & 0,49 & 1,3 & 0,41 \\
\hline Cool & 1,51 & 1,58 & 0,07 & 1,3 & 0,21 \\
\hline Vzrušující & 1,57 & 1,41 & 0,16 & 1,5 & 0,07 \\
\hline Současný & 2,03 & 2,26 & 0,23 & 1,81 & 0,22 \\
\hline Originální & 2,01 & 2 & 0,01 & 2,09 & 0,08 \\
\hline Maloměstský & 3,2 & 2,86 & 0,34 & 3,33 & 0,13 \\
\hline Vůdčí & 3,06 & 2,65 & 0,95 & 3,39 & 0,33 \\
\hline Sebejistý & 3,36 & 2,93 & 0,43 & 4,17 & 0,81 \\
\hline Inteligentní & 2,49 & 3,09 & 0,60 & 2,73 & 0,24 \\
\hline Úspěšný & 2,68 & 3,08 & 0,40 & 2,98 & 0,3 \\
\hline Pracovitý & 2,68 & 3,2 & 0,52 & 2,84 & 0,16 \\
\hline Odborný & 2,41 & 2,73 & 0,32 & 2,27 & 0,14 \\
\hline Ochranářský & 3,29 & 2,86 & 0,43 & 2,48 & 0,81 \\
\hline Okouzlující & 1,79 & 1,68 & 0,11 & 1,68 & 0,11 \\
\hline Jedinečný & 2,01 & 2,03 & 0,02 & 2,63 & 0,62 \\
\hline Mužný & 2,34 & 1,89 & 0,45 & 2,42 & 0,08 \\
\hline Drsný & 2,38 & 1,68 & 0,7 & 2,51 & 0,13 \\
\hline Houževnatý & 3,01 & 2,6 & 0,41 & 3,22 & 0,21 \\
\hline Nezávislý & 2,28 & 2,38 & 0,1 & 2,64 & 0,36 \\
\hline Směrodatná odchylka & 0,49 & 0,46 & 0,22 & 0,69 & 0,23 \\
\hline Celková odlišnost & & & 11,42 & & 12,1 \\
\hline Prưměrná odlišnost & & & 0,32 & & 0,34 \\
\hline Variační koeficient & & & 0,684 & & 0,672 \\
\hline
\end{tabular}

